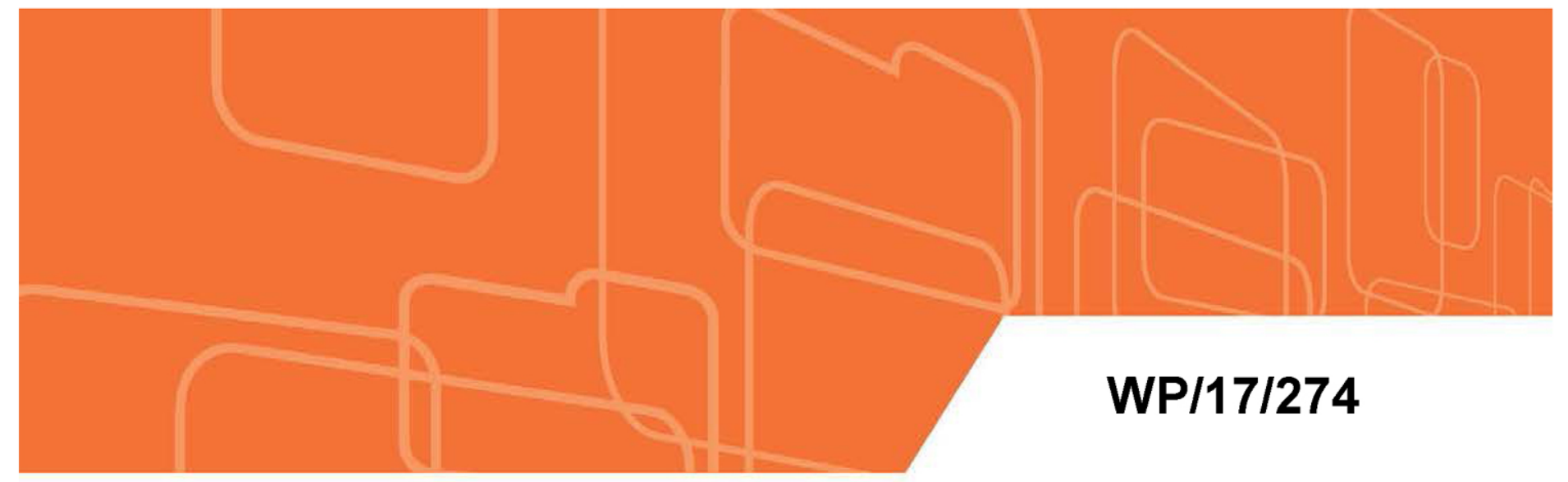

\title{
Crisis and Reform: The 1893 Demise of Banca Romana
}

by Marco Pani

IMF Working Papers describe research in progress by the author(s) and are published to elicit comments and to encourage debate. The views expressed in IMF Working Papers are those of the author(s) and do not necessarily represent the views of the IMF, its Executive Board, or IMF management. 


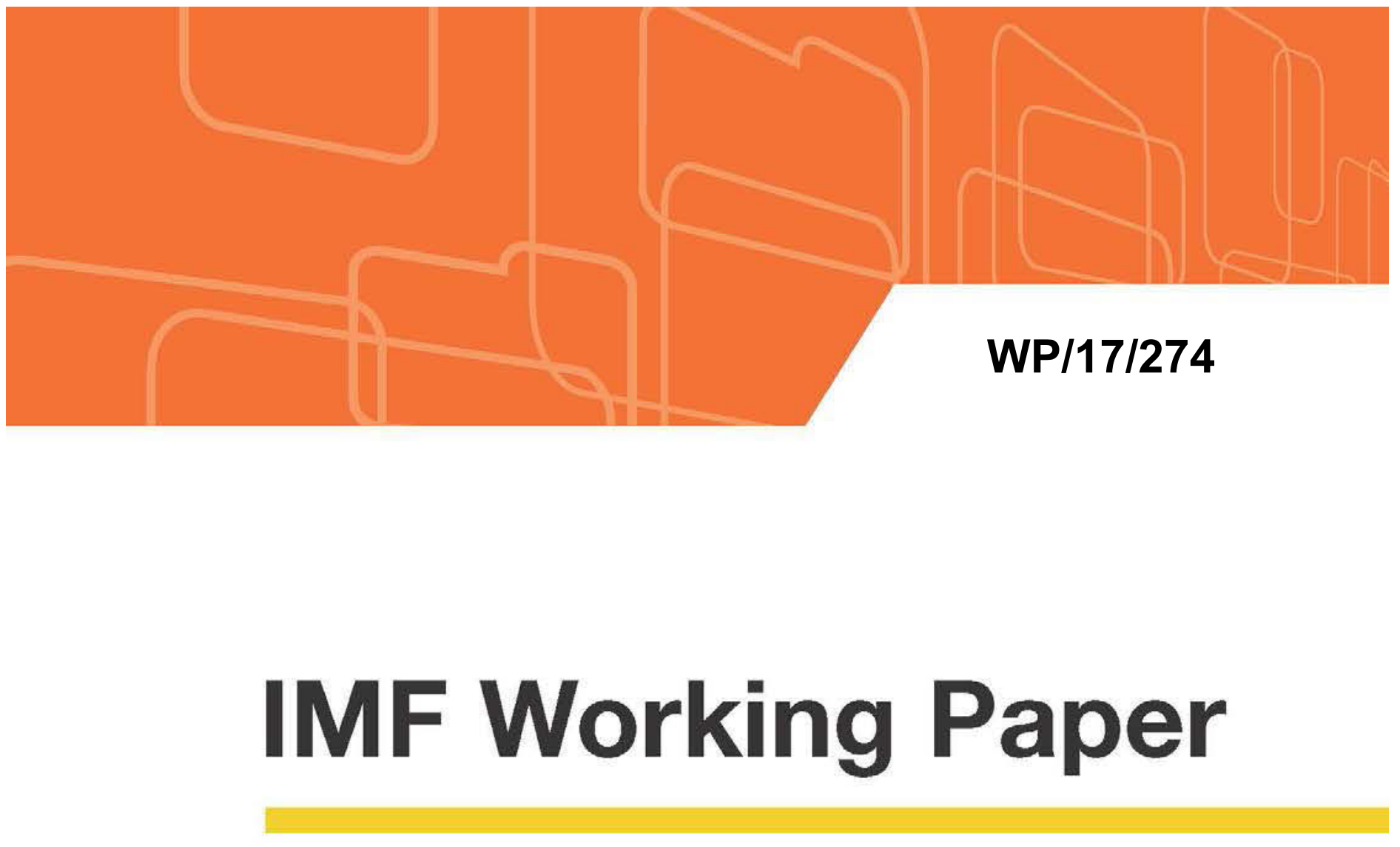

Crisis and Reform: The 1893 Demise of Banca Romana

by Marco Pani

IMF Working Papers describe research in progress by the author(s) and are published to elicit comments and to encourage debate. The views expressed in IMF Working Papers are those of the author(s) and do not necessarily represent the views of the IMF, its Executive Board, or IMF management.

I N T E R N A T I O N A L M O N E T A R Y F U N D 
Monetary and Capital Markets Department

\title{
Crisis and Reform: The 1893 Demise of Banca Romana \\ Prepared by Marco Pani ${ }^{1}$ \\ Authorized for distribution by Ulric Eriksson von Allmen
}

December 2017

\section{IMF Working Papers describe research in progress by the author(s) and are published to elicit comments and to encourage debate. The views expressed in IMF Working Papers are those of the author(s) and do not necessarily represent the views of the IMF, its Executive Board, or IMF management.}

\begin{abstract}
More than a century later, the Banca Romana crisis still provides useful insights on the challenges of preserving financial stability. This paper reviews the case and discusses implications that can be relevant today. The crisis was spurred by an unsustainable credit expansion encouraged by capital inflows, which provoked an asset price bubble and other imbalances. A system of corruption and collusion with politicians and journalists enabled the bank managers to run risky and illegal operations - effectively, asset-stripping - undetected and unhindered. As a result, it would not have been easy for an observer not endowed with investigative powers to detect the mounting risks, while the government, which had these powers, failed to take action when needed and concealed critical information from the public. When the crisis erupted, its resolution was facilitated by a previous, decade-long debate on the reform of the banking system which had led to the exploration and development of possible solutions that could then be rapidly implemented.
\end{abstract}

JEL Classification Numbers: E42; G01; G21; D83; N23.

Keywords: Banca Romana; Italy; issuing banks; banking crisis; bank supervision; corruption. Author's E-Mail Address: MPani@imf.org

\footnotetext{
${ }^{1}$ I am grateful to Jihad Alwazir, Magally Bernal, Giovanni Cucinotta, Rishi Goyal, Ulric Eriksson von Allmen, Gabriela Maciel, Rodolfo Maino, Joannes Mongardini, Steven Phillips, Manmohan Singh, Anke Weber, and other IMF colleagues for valuable comments and suggestions, and to Margarita Aguilar and Vanessa Guerrero for their precious help with editing this paper. Any remaining errors or inaccuracies are my sole responsibility.
} 
Contents

ABSTRACT

I. INTRODUCTION

II. BACKGROUND OF THE CRISIS

A. Historical Context

B. Banca Romana

C. The Italian Banking System

III. THE CRISIS

A. The Run-Up to the Crisis: Capital Inflows and Credit Expansion

B. Developments at Banca Romana and Other Issuing Banks

C. The Crisis and the Bankruptcy

D. Resolution and Aftermath (1893-94)

E. The Recovery After the Crisis

IV. DISCUSSION

REFERENCES

\section{BOXES}

1. Banca Romana: Irregularities Highlighted by the Alvisi Investigation

2. Selected Issues Deplored or Disapproved by the Mordini Committee

3. Law Bills for the Reorganization of the Issuing Banks, 1864-94

$\underline{35}$

\section{FIGURES}

1. Italy: Composition of GDP by Sector, 1890

2. Italy: Regional Distribution of Banks, 1890

3. Italy: Net Inflow of Capital, 1878-1894

4. Italy: Real GDP Growth, 1862-1913

5. Italy: Bilateral Real Exchange Rate (RER) vis-à-vis France and the U.K., 1861-1913

6. Italy: Bank Loans, 1874-1894

7. Northern and Central Italy: Percent of the Population Living in the Major Cities, 18611911

8. Italy: Investment in Housing and Value-Added in Construction, 1878-1893

9. Italy: Real Growth Rates of Selected Sectors, 1861-1911

10. Banca Romana: Circulation, Portfolio, and Private Sector Credit, 1870-1893

11. Banca Romana: Selected Balance Sheet Items, 1870-93

12. Italy: Fiscal Balance, 1861-1913

13. Italy: Growth and Credit Cycles, $1874-93$

14. Italy, Exports, 1881-90

15. Italy: Annual Rate of Money Growth, 1874-89

17. Italy: Average Interest Rate on Short-Term Bank Loans, 1874-98

$\frac{23}{24}$


18: Italy: Average Annual Increase in Bank Loans by Type of Bank, 1874-93___ 25

19. Italy: Average Annual Growth in Bank Loans, 1974-1913 _ _ 26

21. Banca Romana: Share Price at the Rome Stock Exchange, December $1892 \_31$

22. Banca Romana: Share Price in the Rome Stock Exchange, January-February $1893 \_$__

23. Italy: Real GDP Growth, Inflation, and Credit Expansion, 1874-89 ___ $\underline{51}$

\section{TABLES}

1. Banca Romana: Selected Financial Stability Indicators, 1877-92 $\underline{20}$

2. Italy: Capital-Asset Ratio of the Six Issuing Banks, 1877-92

3. Italy: Cash Holdings in Percent of Circulation, 1877-92

4. Estimates of the Total Losses Incurred by Banca Romana

5. Bank of Italy:Net Profits and Dividends, 1871-1912 $\underline{47}$

6. Estimated Sharing of the Losses of Banca Romana $\underline{48}$

\section{APPENDICES}

A. Main Legislation Governing Currency Issue and the Issuing Banks, 1861-95

B. Legislation Extending the Legal Tender of Banknotes, 1874-93 
The propensities to swindle and be swindled run parallel to the propensity to speculate during a boom. Crash and panic... induce still more to cheat in order to save themselves.

Charles P. Kindleberger ${ }^{2}$

A me pare che la baldanza del governatore della Banca Romana sia venuta precisamente dal silenzio tenuto tuttora. Egli è, che io credo, che abbia acquistato la sicurezza della impunità; egli è convinto (forse, falsamente convinto) che nulla si pubblisherà su di lui, sulle cose della sua Banca. Noi non possiamo e non dobbiamo tacere... ${ }^{3}$

Napoleone Colajanni ${ }^{4}$

\section{INTRODUCTION}

Rome, December 20,1892. As the city prepares to celebrate Christmas, Parliament debates a law that would prolong for another six years the exclusive privilege to issue banknotes granted to six banks. In what already promises to be a contentious debate, a member of the radical opposition, the Hon. Napoleone Colajanni, surprises the audience by denouncing a series of irregularities and violations that call into question the financial health of one of those banks and, more generally, the viability of the entire note issuing system.

In this way the general public, which until then had only heard sparse and unconfirmed rumors, became aware of the crisis at Banca Romana, a systemically important institution with major political connections whose demise led to the establishment of the Bank of Italy, to this day the Italian central bank. Three years before a ministerial investigation already had detected serious problems at that bank, but its findings had been concealed from the public by a government concerned about the potential financial and political repercussions and whose members had embarrassing personal deals with the bank. From a broader perspective, the crisis revealed the lingering weaknesses of the Italian financial system and accelerated its reform.

A close look at these events can still provide interesting insights that can better orient ongoing efforts to enhance the stability of the financial system. What caused the crisis in the first place? What hampered a prompter detection and intervention? How was the problem eventually resolved? Who paid the costs, and what were the long-term implications?

\footnotetext{
${ }^{2}$ Kindleberger (1996), p.66.

3 "It seems to me that the boldness of the governor of Banca Romana came precisely from the silence that has been kept to date. I believe that he has acquired the certainty of impunity; he is convinced (possibly, unduly) that nothing will become public about him and on the affairs of his bank. We cannot and we should not remain silent..." [this paper's translation]

${ }^{4}$ Atti Parlamentari (1892), p. 711.
} 
Political connections, up to the highest level, figure prominently throughout the crisis and were a major contributing factor; the press also played a role, both by failing to exert an independent check on the banks and by providing self-interested support to their positions on relevant policy issues. In a broader perspective, the crisis stemmed from some key economic, institutional, and political weaknesses affecting the newly established Kingdom of Italy, where an inflow of foreign capital spurred an unsustainable real estate speculation that provided incentives for abuse. These problems were compounded by specific government policies on trade, exchange rates, and money supply.

The crisis precipitated a long due reform of the banking system that provided a more supportive environment for the industrial expansion that eventually took off around the turn of the century. In historical perspective, the crisis can be seen as the completion of the transition from a system characterized by the lingering legacy of institutions pre-dating the unification of the country to a more modern and rational arrangement more apt to support the transition to an industrial economy. ${ }^{5}$

What lessons can be drawn from this experience that can be relevant today? For a start, the developments at Banca Romana highlight the difficulty of obtaining timely, accurate information. Up to the last moments, bank managers and government officials continued to deny that a problem even existed, despite the fact that the content of an official report on the situation had leaked to the public. This is not an uncommon occurrence; in comparable cases, even today, not just external observers, but even technical experts not vested with the necessary investigative powers may encounter severe difficulties at detecting the real extent of the problem and may even fail to detect the presence of a problem, misled by the favorable assessment provided by managers, passive (perhaps even collusive) media, complacent analysts and - in some cases, such as that of Banca Romana - even public officials responsible for supervision and oversight. Piercing beyond this wall of deception requires a careful collection and review of information from a variety of sources, and can be quite challenging.

On the other hand, the few people who were fully aware of the actual conditions of Banca Romana (the top managers of the bank, of course, but also some ministers and government officials) must have understood that they were not sustainable for long. Why did they allow them to deteriorate without taking timely action? And what convinced the general public to continue to accept claims on the bank (mainly in the form of banknotes), when rumors started to circulate that sounded even more insidious in the absence of a credible information channel? One possible answer is that everyone may have relied on the widespread perception that the bank benefited from an implicit government guarantee. Since the legal tender of the bank's nonconvertible notes had been established by law, the argument went, the government had a political and moral - if not legal - obligation to bail out the bona fide creditors of the bank (or at least the holders of its notes) if the latter incurred financial difficulties; but then, since everybody relied on this implicit guarantee, a strained situation might continue to fester

\footnotetext{
${ }^{5}$ This view is not universally shared. For instance, "free-market" economists at the time deplored the reform as a move to an inefficient monopoly of money supply that would render the system more unstable.
} 
indefinitely without triggering a crisis - on one hand, allowing time to take corrective action but, on the other, encouraging procrastination.

The experience with this crisis confirms that such procrastination can be very costly, and that problematic cases should be resolved as soon as possible to prevent unnecessary losses (an argument frequently reiterated today). It also highlights that strong incentives may play in the opposite direction, especially when corruption and fraud are involved. Hence, investing the supervisory authorities with the powers to obtain accurate timely information and to intervene accordingly may not be a sufficient safeguard, unless the same authorities are also adequately sheltered from political influence and regulatory capture and unless they are credibly held accountable for negligence or for failing to intervene at the right moment. Designing proper incentive schemes for supervisors (and for the entities they supervise) may thus require an accurate understanding of the underlying political economy.

Although the public Treasury did not directly bail out the bank's creditors, the costs of restructuring the banking system (including tax rebates granted to the rescuing institution and the prolonged suspension of convertibility) were ultimately borne by the general public. A significant share of the losses of the bank were borne by the taxpayers, in ways that were not fully transparent and thus eluded a full public scrutiny. Such an outcome is probably not uncommon, and points to the importance of enhancing the transparency of subsidies, bailouts, and more generally fiscal (or quasi-fiscal) operations; and of preparing bank resolution and crisis management schemes in advance, so that the principle guiding how the burden of adjustment should be distributed among different stakeholders can be defined more accurately and equitably, reducing the scope for abuses and inefficiencies.

The Banca Romana crisis provides an example of how a reform that has been stalled for years under the resistance of vested interests can be precipitated by a crisis. In such cases, building on proposals and schemes that have previously been developed and discussed can enable the authorities to rapidly secure the necessary consensus to implement viable and effective solutions.

\section{BACKGROUND OF THE CRISIS}

\section{A. Historical Context}

The Italian peninsula, which for several centuries had been divided in multiple small states, was unified into a single political entity in five steps over a span of sixty years, from 1859 to 1918. The bulk of the country was united in 1860, when the Kingdom of Sardinia incorporated the Kingdom of the Two Sicilies in the south and a large part of the Papal States. ${ }^{6}$ Venice and its mainland were annexed to the Kingdom in 1866, while Rome and its territory remained independent under the Pope's jurisdiction until 1870. Soon after its annexation, Rome became the new capital of the Kingdom.

\footnotetext{
${ }^{6}$ The Papal States, whose capital was Rome, were until 1870 an independent country in central Italy governed by the secular jurisdiction of the Pope.
} 
The Kingdom of Italy was governed by the Constitution (Statuto) granted by King Charles Albert in 1848, which attributed large powers to the King and provided for a bicameral Parliament including a Senate (Senato) whose members were appointed for life by the King, and a Chamber of Deputies (Camera dei Deputati), whose members were elected. In practice, the center of power rested with the Chamber of Deputies, and the executive branch of government was led by a Council of Ministers that was effectively responsible to the Chamber. $^{7}$

No political parties existed in the modern sense of the word; members of the Chamber could be roughly divided into a large group of insiders, who took turns in forming rather fluid and unstable government coalitions and alternated to cabinet posts, and a smaller group of outsiders (mostly taking fringe, or radical, positions), who were always in opposition and provided an independent check on the actions of the executive. While insiders were broadly divided into Left and Right, ${ }^{8}$ this distinction was not clear-cut and people of either sides could join various coalitions according to a complex and shifting system of alliances. Coalitions and cabinets were short-lived, but policies were much more stable as cabinet positions were generally filled by the same group of insiders.

While elective, the Chamber was poorly representative of the population at large. Until 1882, only half a million people (one out of 60) had the right to vote. In 1882 the suffrage was extended to include 2 million people, but this still covered a mere 7 percent of the population. $^{9}$

\section{B. Banca Romana}

Banca Romana was founded in $1833^{10}$ under the Pope's jurisdiction and was authorized to discount bills, extend loans, collect deposits, and issue banknotes and other bearer's securities. After the fall of the short-lived Roman Republic, in 1850 the bank was renamed Banca dello Stato Pontificio and obtained the monopoly of currency issue, deposit collection, and credit in the Papal States. When Rome was annexed to the Kingdom of Italy in 1870, the bank retook its former name of Banca Romana and preserved the right - though not the

\footnotetext{
${ }^{7}$ See for instance Mack Smith (2003).

${ }^{8}$ Known as the "Historic Right" and "Historic Left." The Right controlled the Executive until 1876, when the baton was passed to the Left.

${ }^{9}$ Data from ISTAT. The proportion of households represented in Parliament (and hence the degree of representation by class or geographic area) was however significantly larger. Taking into account that more than 40 percent of the population was below 20 years of age and that women wound not gain the right to vote until 1945, after 1882 the number of household including at least one voter may have ranged between one-fifth and one-fourth.

${ }^{10}$ Spinelli and Fratianni (1997) and di Nardi (1953). According to Poddi (2016), the origins of Banca Romana can even be traced back to a Cassa di Sconto di Roma established in 1825.
} 
monopoly - to issue banknotes. ${ }^{11}$ The bank's capital was increased to 15 million lire in $1874,{ }^{12}$ bringing its authorized note circulation to about 0.4 percent of GDP and 6 percent of total note circulation.

Under the direction of Ludovico Guerrini (1870-81) Banca Romana was managed prudently and its circulation remained within the legal limits. ${ }^{13}$ When Guerrini died in 1881, however, he was succeeded as Governor by a man of a very different character. Commendator Bernardo Tanlongo was born in Rome on September 3, 1820, left school at the age of 13, and proceeded through a variety of trades in commerce and banking, where he often played the part of agent or intermediary, standing as figurehead in deals in which a wealthy or noble person did not want his name to appear. Endowed with outstanding social skills but few moral scruples, he established strong personal connections with influential people: Roman aristocrats and businessmen, industrialists and top government officials, Jesuit clerics and freemasons, reaching all the way to the Royal Family. He acted as their agent in real estate speculations and, later, he also speculated on his own account. After his appointment as governor of Banca Romana, on one side he used these connections to gain political cover for his not fully legal operations, and on the other he used the bank's assets to strengthen these connections, extending and rolling over unsecured personal loans (and other payments) to politicians, journalists, and other powerful supporters. ${ }^{14}$ At the peak of his career, in November 1892, Tanlongo was nominated Senator by the King, but the appointment never became effective.

\footnotetext{
${ }^{11}$ Royal Decree of December 2, 1870, No. 6064; see also di Nardi (1953), Grapanzano and Giulianini (2010), and Poddi (2016). The bank was compensated for the loss of monopoly issue in the area of Rome with a grant of 2 million lire to be paid pro rata by all the issuing banks that opened branches in that area.

12 According to the data published by de Mattia (1967), the capital of Banca Romana amounted to 5.375 million in 1870, 3.680 million (plus reserves) in 1871, and 5 million (plus reserves) from 1872 to 1873; capital (excluding reserves) increased to 10 million in 1874 and to 15 million in 1875 . Article 10 comma (i) of the Law of April 30, 1874 No. 1920 provided that "Banca Romana is authorized to issue, within six month of publication of this law, the second series of 5,000 shares and, within the three successive months, the third series of 5,000 additional shares." (this paper's translation; emphasis added). Each share had a nominal value of 1,000 lire.

${ }^{13}$ Grapanzano and Giulianini (2010). According to these authors, Guerrini's first name was Giuseppe; other sources (Quilici, 1935, Macrì, 1993, and Poddi, 2016) refer to him as Ludovico.

${ }^{14}$ See for instance Alvi (2004); Bertoldi (1993); Corriere della Sera, January 20, 1893, July 31, 1896, and August 1, 1896; Grapanzano and Giulianini (2010); Macrì (1993), Nascimbeni (1974); Poddi (2016); Quilici (1935); and Talamona (1993).
} 


\section{The Italian Banking System}

In 1890, when the crisis of Banca Romana was building up, the Italian financial system (credit and insurance) contributed to less than 1 percent of GDP (Figure 1). ${ }^{15}$ Its main component, the banking sector, was composed of about 1,100 entities, including 153 banks, 216 savings banks (casse di risparmio), and about 700 credit unions (banche popolari). ${ }^{16}$

\section{Figure 1. Italy: Composition of GDP by Sector, 1890}

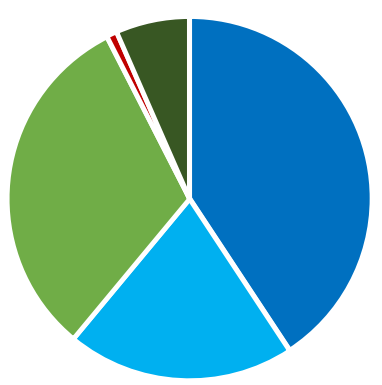

- Agriculture - Industry - Nonfinancial Services ॥ Financial Services ॥ Other

Sources: ISTAT/Bank of Italy.

The banking sector was dominated by six "issuing banks"17 that were authorized to issue banknotes and accounted for more than one-half of its value-added and for about one-third of its loans. Among them, the Turin-based Banca Nazionale nel Regno d'Italia (BNR), with assets for 10 percent of GDP and an extensive network of branches throughout the Kingdom, had a clearly dominant position.

This arrangement was rather peculiar at the time. With the exception of Argentina, other countries either had a single central bank (like France or England), or a much larger number of issuing banks in close competition with one another (like Scotland, Ireland, and the United States). ${ }^{18}$

Besides the issuing banks, there were a few large commercial banks, mostly funded with foreign (French) capital, such as Banca Generale and Credito Mobiliare. Total banks' assets

\footnotetext{
${ }^{15}$ By comparison, between 1992 and 2010 its contribution to GDP has been, depending on different estimates, between 3 and 5 percent: de Bonis et al. (2012)

${ }^{16}$ Natoli et al. (2016). There were also several local stock markets, the largest at Genoa.

${ }^{17}$ Besides Banca Romana, these included Banca Nazionale nel Regno d'Italia (BNR), Banca Nazionale Toscana, Banca Toscana di Credito, Banco di Napoli, and Banco di Sicilia.

${ }^{18}$ The United States did not have a central bank but, after the Civil War, banks chartered as national banks could issue banknotes backed by federal bonds or reserves under the supervision of the Office of the Comptroller of the Currency: see for instance, Giani and Vannini (2010).
} 
amounted to about one-half of GDP ${ }^{19}$ and total bank capital to about 8 percent of GDP. ${ }^{20}$ Base money ${ }^{21}$ amounted to 19 percent of GDP, of which roughly 40 percent were coins and the rest banknotes. ${ }^{22}$ Banks were most active in the North, ${ }^{23}$ especially in the north-western provinces of Lombardy, Piedmont, and Liguria, where industrialization was at a comparatively advanced stage (Figure 2).

Figure 2. Italy: Regional Distribution of Banks, 1890

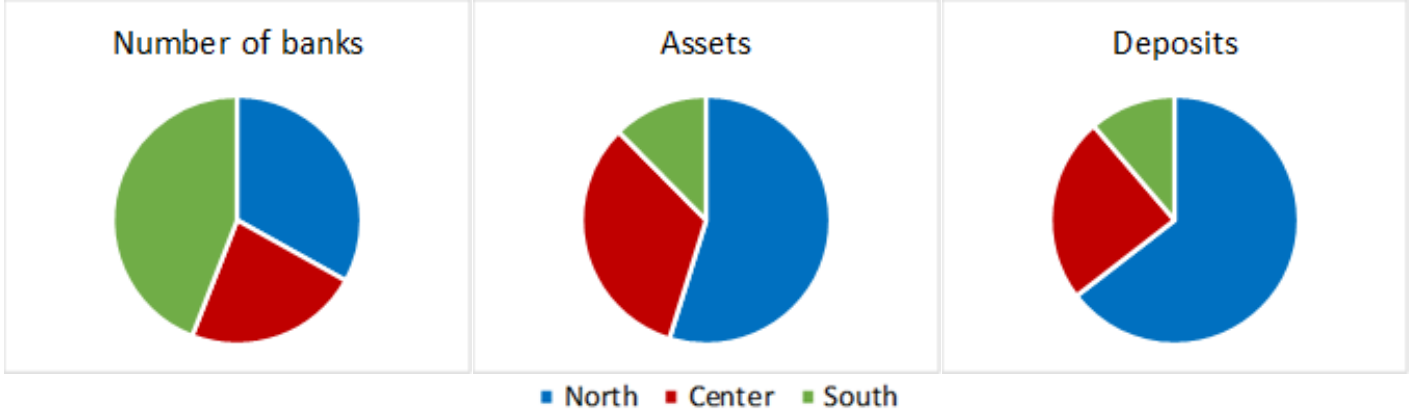

Source: Natoli et al. (2016).

Soon after the national unification, the currencies of Italy had been unified into the new lira italiana ${ }^{24}$ under a bimetallic standard, ${ }^{25}$ but paper notes continued to be issued by five authorized issuing banks, which became six with the annexation of Rome, plus - for some time - a number of unauthorized banks. ${ }^{26}$ In 1866 the government had imposed on these notes the corso forzoso, a temporary suspension of their convertibility into metal, with the expectation that it would be resumed at the previous rate in the near future (it happened in

\footnotetext{
${ }^{19}$ Including those of the issuing banks, amounting to about 18 percent of GDP; data from Bank of Italy, de Bonis and Silvestrini (2013), and de Mattia (1967).

${ }^{20} 1$ billion lire, including the capital and reserves of the issuing banks (331 million lire): see de Mattia (1967).

${ }^{21}$ Banknotes and coins in circulation, excluding bank deposits. Using the definition of Spinelli and Fratianni (1991), which also includes deposits at issuing banks and post offices, base money amounted in 1890 to about 24 percent of GDP.

22 De Bonis and Silvestrini (2013), and de Bonis et al. (2012). Banknotes overtook coins in circulation in 1867. Until 1884 the cash (notes and coins) circulation remained larger than the stock of deposits.

${ }^{23}$ In terms of deposit collection and investment of assets. The number of banks was evenly distributed across the territory, and slightly higher in the South.

${ }^{24}$ Law of August 24, 1862 No. 788 (legge Pepoli).

${ }^{25}$ At the then prevailing conversion rate of 15.5 ounces of silver for one ounce of gold.

${ }^{26}$ The circulation of unauthorized banks peaked at 37 million lire, about 3 percent of the total, in 1872 (de Mattia, 1967).
} 
1883). In 1874 the "Minghetti Law"27 had granted an exclusive right to issue banknotes to the six existing issuing banks, imposed a cap on the circulation and a reserve requirement of one third ${ }^{28}$ and given legal tender to the banknotes wherever the bank that issued them had a branch or a representative office; ${ }^{29}$ the notes, however, had remained nonconvertible. Public supervision over banks was vested with the Ministry of Agriculture, Industry, and Trade (hereafter, Ministry of Agriculture), ${ }^{30}$ and covered only the issuing banks, partly because - as discussed below - consensus, at the time, leaned against government intervention in this area. ${ }^{31}$

\section{THE CRISIS}

\section{A. The Run-Up to the Crisis: Capital Inflows and Credit Expansion}

After a decade of broadly stable economic conditions, in the 1880s Italy experienced a credit boom. When France resumed convertibility in 1878, the Italian authorities followed suit; in 1883 convertibility was restored at the previous official parity - as expected under a metal standard at the time - inducing the lira to appreciate by about 10 percent against the French franc and Sterling. The resumption of convertibility, at a moment of ample international liquidity, triggered a sustained inflow of short-term capital in various forms, including the placement of Italian stocks and bonds and the discount of bills and commercial paper in Paris and other foreign financial centers (de Cecco, 1993; Confalonieri, 1974). Net capital flows, which had fluctuated around zero with an overall negative balance between 1870 and 1882, turned positive at about 2-21/2 percent of GDP between 1883 and 1890 (Figure 3). Prompted by these inflows, between 1883 and 1889 credit grew by 11 percent a year on average, to 34 percent of GDP.

\footnotetext{
${ }^{27}$ Law of April 30, 1874, No. 1920.

${ }^{28}$ Although the issuing banks were required to convert their notes on demand, they could fulfil this requirement by using consortium bills issued jointly by the banks against a 940 million lire loan to the Government (Law of April 30, 1874, No. 1920, Art. 15). These bills amounted to about two-thirds of total note circulation, and were phased out in ten years after convertibility was restored in 1883 .

${ }^{29}$ The law mandated the six issuing banks to offset their reciprocal note balances on a monthly basis (so-called riscontrata), settling the difference in consortium bills. In practice, this provision (which would have favored the BNR which, as the dominant bank, had generally active balances) was largely disregarded or suspended, especially in later years.

${ }^{30}$ Regulation approved with Royal Decree January 21, 1875, No. 2372 (published on February 25), Art. 1; formally, the authority was vested with the Ministry of Finance, which delegated it to the Ministry of Agriculture. All important measures were to be taken in agreement between the two Ministries.

${ }^{31}$ Commercial banks were regulated under the looser, more general provisions of the Code of Commerce. The Ministry of Agriculture was briefly suppressed in 1877, when the Treasury was established, but it was restored less than one year later under the pressure of agricultural and industrial interests that considered it as a vehicle to influence government policy: see Cardarelli (2006).
} 


\section{Figure 3. Italy: Net Inflow of Capital, 1878-1894 (percent of GDP)}

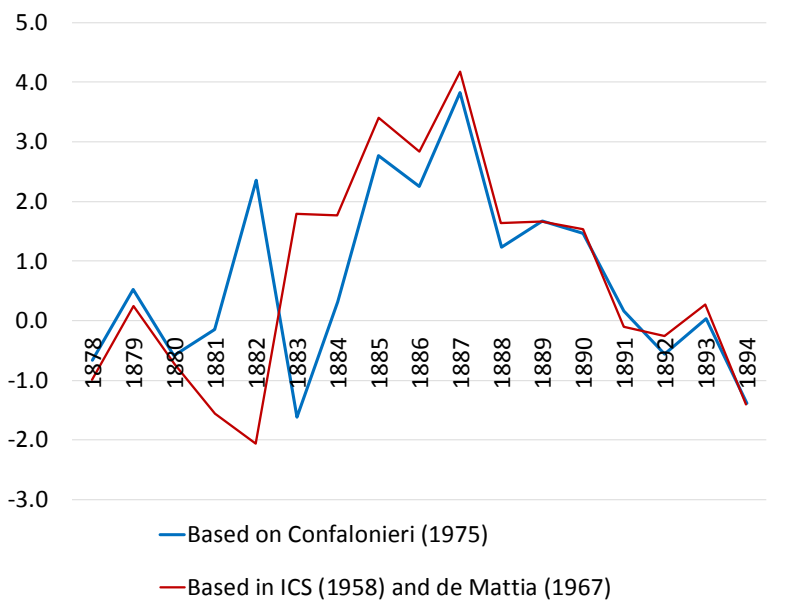

Sources: Estimates based on Confalonieri (1974), ICS (1958), and de Mattia (1967).

With limited viable investment opportunities (the industrial sector was still at an incipient stage, especially outside the north-western provinces, and infrastructure - such as railways was just starting to expand), these inflows failed to promote a significant acceleration of growth. In the four years from 1883 to 1887 real GDP grew at an average rate of 1.9 percent per year, roughly the same pace of the previous decade (Figure 4).

The capital inflow induced a real exchange rate appreciation, a worsening of the current account balance, and an increase in asset prices, with no significant effect on productivity or growth. The real exchange rate had already started to rise in the run-up to the resumption of convertibility, between 1879 and 1883, when it appreciated by 8 percent vis-a-vis the French franc, reflecting the nominal appreciation and a concomitant narrowing of the price differential. ${ }^{32}$ After the resumption of convertibility, the real exchange rate appreciated further against the French franc by an additional 11 percent between 1883 and 1887 (and by 18 percent against Sterling), as wholesale prices in Italy failed to decline in line with those in its trading partners (Figure 5).

These developments resulted in a loss of competitiveness that posed an additional drag to Italy's incipient industrial development. Between 1883 and 1887, the value of exports declined by 16 percent $^{33}$ and the current account balance registered an average annual deficit of about 3 percent of GDP.

\footnotetext{
${ }^{32}$ Estimates based on wholesale prices from Spinelli and Fratianni (1991).

${ }^{33}$ It would decline even further after 1887, despite a marked correction in the real exchange rate, as a result of the trade war with France.
} 
Figure 4. Italy: Real GDP Growth, 1862-1913

(in percent)

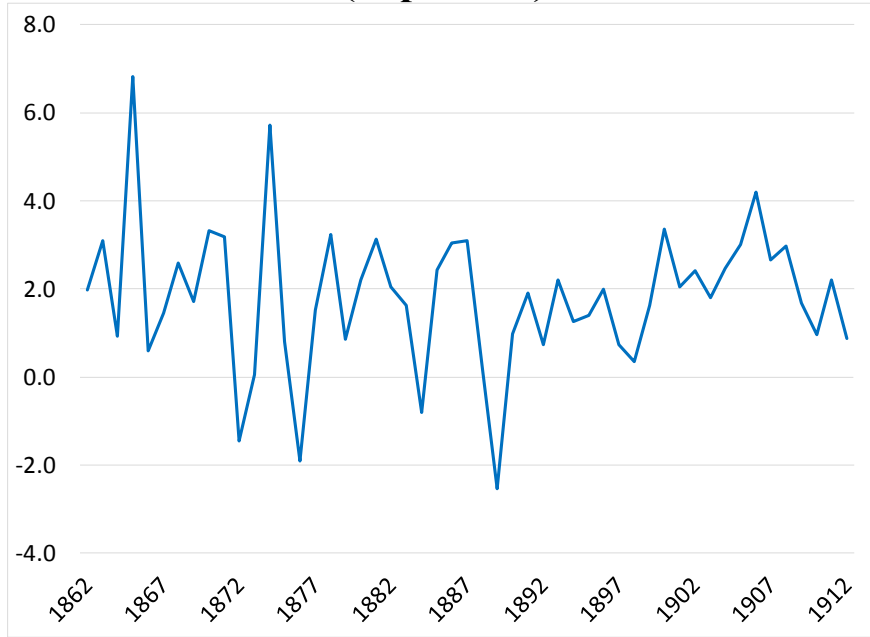

Sources: ISTAT/Bank of Italy.

Figure 5. Italy: Bilateral Real Exchange Rate (RER) vis-à-vis France and the U.K., 1861-1913 (index)

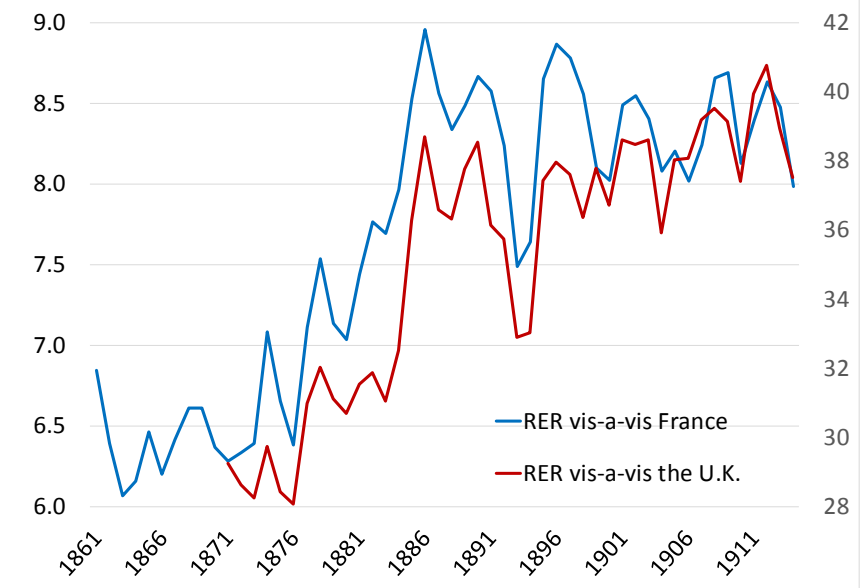

Sources: estimates based on Spinelli and Fratianni (1991). 
The current account deficit, however, did not absorb all the net inflow of capital; between one-fifth and one-third of the total ${ }^{34}$ (a cumulative amount equivalent to about 3.5 percent of GDP) remained in the country in the form of metal coins in circulation and net foreign assets of the issuing banks, ${ }^{35}$ fueling a credit boom and an unsustainable increase in asset prices. Between 1883 and 1889 the total amount of loans extended by the banks almost doubled (from 2.2 to 4.1 billion lire), rising from 20 to 34 percent of GDP (Figure 6). In part, this expansion reflected the ongoing development of the sector from a very low base; a growing number of istituti di credito mobiliare (banks investing in stocks and bonds), mostly set up or financed with foreign (French) capital, started providing long-term funding, although the bulk of bank credit in Italy remained, at least nominally, short-term. These credits, however, went only in part to finance industrial initiatives; the rest went into real estate and ended up fueling a speculative bubble. ${ }^{36}$

The movement of the capital to Rome in 1870 sparked a local real estate speculation. This city, which counted a mere 220,000 inhabitants in 1870 , doubled its population over the next 20 years, attracting 40,000 civil servants, an indefinite number of people revolving around the government and the Court, and job seekers from all parts of Italy. The same trend also affected other cities (most notably Naples), as political unification and economic development spurred a movement to the major urban centers (Figure 7).

Value-added in construction, which had remained broadly constant in real terms in the first decade after unification, increased at an average rate of 3.7 percent a year between 1869 and 1886, two percentage points above real GDP growth; similarly, expenditure on housing increased at an annual average rate of 5 percent (Figures 8, 9). ${ }^{37}$ The credit expansion gave additional impetus to these trends.

\footnotetext{
${ }^{34}$ About 400 million lire.

${ }^{35}$ About 280 million lire, including (mainly) reserves of precious metals (gold and silver), as well as claims on foreign entities, and certificates convertible in gold: data from Spinelli and Fratianni (1991), taken in turn from de Mattia (1967).

${ }^{36}$ The real estate boom is documented by contemporary anecdotal evidence (e.g., in contemporary newspaper articles and parliamentary speeches) and by recent studies (e.g., Confalonieri, 1974; Negri, 2003). Gigliobianco et al. (2009) and Gigliobianco and Giordano (2010) explicitly mention a "real estate bubble," and Quilici (1935) reports that property in Rome that a suburban vineyard that was sold for 35,000 lire was re-sold a few years later for half a million lire and sold again after a few months for 2 million; and the price per square meter of properties just outside Porta Pia increased from 3 lire in 1882 to 15 lire in 1884 and 32 lire in 1887.

${ }^{37}$ The increase in asset prices contributed, in turn, to attract foreign capital in search for yield. To some extent, foreign investors may have underestimated the risks involved in the rapid price increase and overestimated its sustainability; they may also have overestimated the buffers provided by their investment intermediaries (such as banks) whose capital, as proved by later events, was not always capable of absorbing the full amount of the losses.
} 
Figure 6. Italy: Bank Loans, 1874-1894

(percent of GDP)

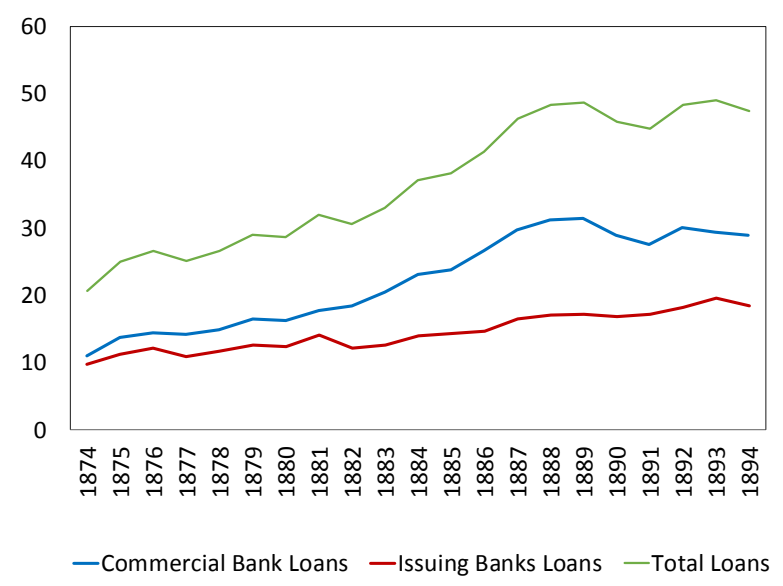

Sources: ISTAT/Bank of Italy.

Figure 7. Italy: Share of the Population Living in the Major Cities, 1861-1911 38 (percent)

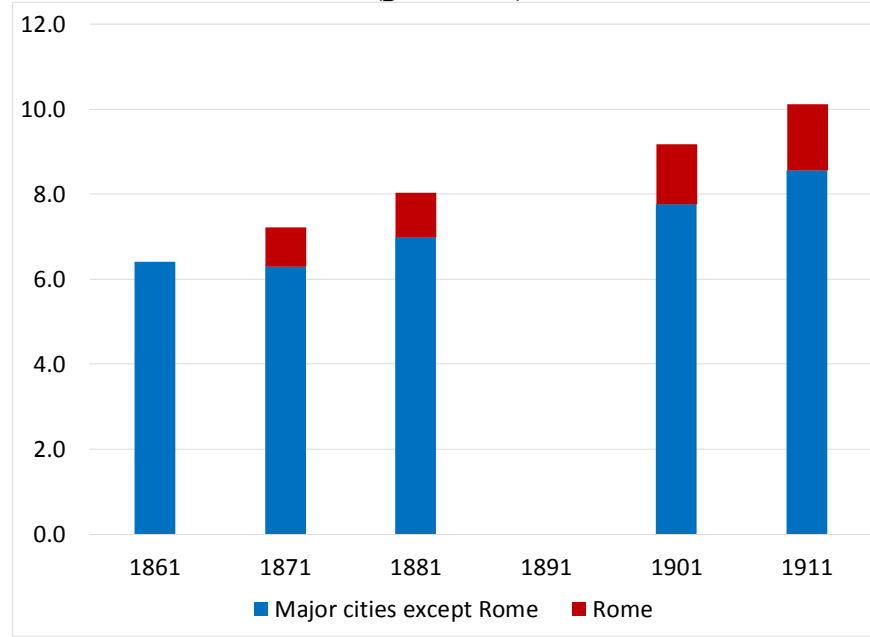

Sources: SVIMEZ (1954) and ISTAT.

\footnotetext{
${ }^{38}$ The cities are Bologna, Florence, Genoa, Milan, Naples, Palermo, Rome, Turin, Venice, and Verona. Data for 1861 do not include Venice and Rome, that were not, at that time, part of the Kingdom of Italy. Data for 1891 are not available.
} 
Figure 8. Italy: Investment in Housing and Value-Added in Construction, 1878-1893 (million of 1911 lire)

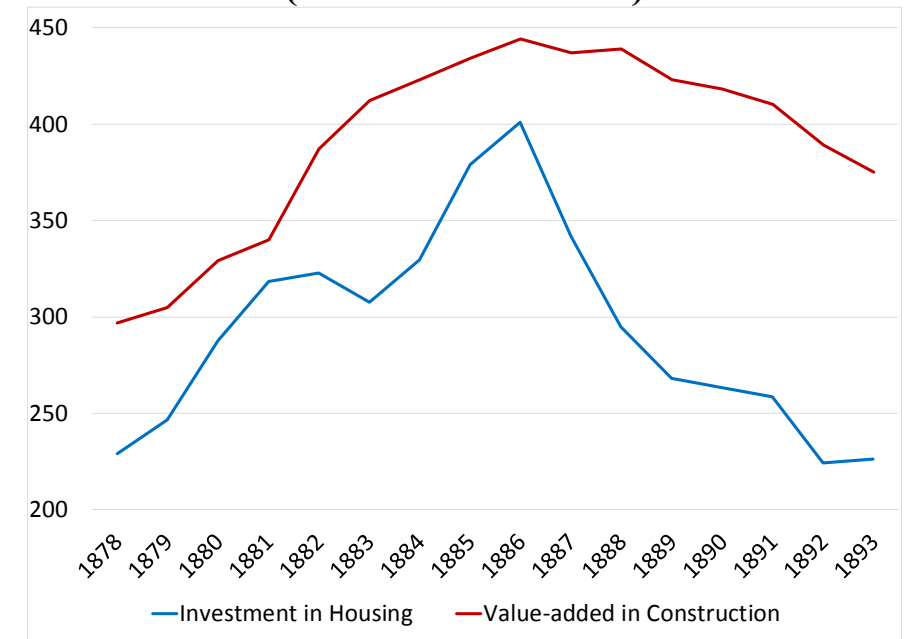

Sources: ICS (1958); ISTAT/Bank of Italy.

Figure 9. Italy: Real Growth Rates of Selected Sectors, 1861-1914 (percent)

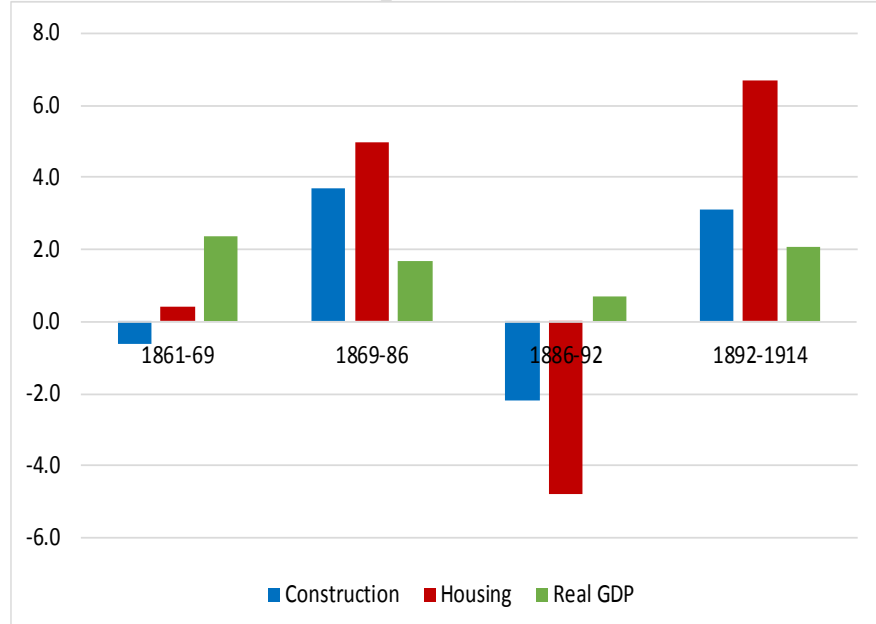

Sources: ISTAT/Bank of Italy.

In 1885 the government inadvertently supported these developments by waiving a provision in the 1874 banking law that would have forced the issuing banks to sterilize their increase in reserves, ${ }^{39}$ thereby allowing the net capital inflows to expand domestic money supply. This, in turn, enabled the commercial banks - whose deposit collection increased by almost 60 percent between 1882 and 1887 - to expand their domestic credit. Issuing banks largely competed with commercial banks for the same customers in the same lines of business and were thus induced to expand their circulation in order to preserve their share of the market; moreover, they financed or re-financed the operations of a growing number of local

\footnotetext{
${ }^{39}$ The waiver allowed the banks to exceed the circulation limits set in the Minghetti Law provided the excess circulation was fully backed by metal reserves. Without this provision, the fixed ceiling on circulation would have forced the issuing banks to reduce their credit as they accumulated excess metal reserves.
} 
commercial banks, savings banks, and credit unions and intermediated the placement of securities and bonds. The funds raised by issuing banknotes cost the issuing banks a "circulation tax" whose effective rate was less than one percent, and could be invested at an average rate above 3 percent (taking account of the one-third reserve requirements), yielding a net margin of more than 2 percent. ${ }^{40}$ Hence, as noted by Confalonieri (1974), the issuing banks had a strong incentive to bring their circulation as rapidly as possible to its legal limit and even to trespass it if they could. The government encouraged this behavior by forbearing such infringements of the ceiling ${ }^{41}$ or regularizing them ex post $t^{42}$ in order to ease the money supply, especially when economic conditions started to deteriorate. ${ }^{43}$

\section{B. Developments at Banca Romana and Other Issuing Banks}

In the capital, Banca Romana was facing a rising demand for credit to finance both investments in property and the politicians' demand for funds for their activities and campaigns. In 1882 the reform of the suffrage had produced a threefold expansion of the electorate, further increasing campaign costs. While other issuing banks (notably BNR and Banco di Napoli) were also active in Rome, Banca Romana enjoyed a dominant position in the local market and the initiative to address the politicians' need for funds was taken primarily by its newly appointed, imaginative, and socially adept governor, who caught the opportunity to strengthen and widen his circle of influential supporters by granting them cheap and often open-ended loans with little or no guarantees. ${ }^{44}$ His beneficiaries included

\footnotetext{
${ }^{40}$ In a regime of convertibility, the quantitative ceiling on circulation had lost is meaning as a monetary anchor but remained in force, posing an undue constraint on issuing banks' activity, yielding an incentive to trespass it. It should be noted that the issuing banks were authorized to invest part of their metal reserves in interest-bearing promissory notes payable in gold.

${ }^{41}$ Aside from the most blatant cases such as Banca Romana's, such infringements were variously justified by the banks, that related them to seasonal or extraordinary factors and gained the government's support (already encouraged by macroeconomic considerations) by ventilating the possibility of rationing credit to sound commercial enterprises in order to comply with the limits. BNR also argued that its excess of circulation was more than offset by the balances of notes of other issuing banks on its balance sheets, which reduced the latter banks' circulation (Confalonieri, 1974).

${ }^{42}$ Most notably with the Law of June 30, 1891 No. 314, that extended them to 4 times the capital or to the average amount of the year 1890, whichever was larger.

43 This is an example of time-inconsistency in monetary policy. In the long term, in a regime of de-facto nonconvertibility, the government wanted to maintain a fixed ceiling on money supply in order to provide a credible anchor to the value of the currency that could, over the long run, support the resumption of convertibility at the previous rate; in the short term, the government wanted to deviate from this anchor (taking advantage of the confidence it induced) in order to support domestic demand through a monetary expansion. The two objectives were, of course, inconsistent, which contributed to the 1992-94 crisis. In response, the law enacted since 1894 included much stricter constraints on the government and the expansion of money supply that supported real economic growth after 1898 resulted largely from an increase in the money multiplier.

${ }^{44}$ Corriere della Sera reported on January 18, 1893 that "in Parliamentary circles they say that from 1876 onwards the political elections have been financed with the money of the issuing banks. In [18]92, more than before; and more with the money of Banca Romana than with that of the other issuing banks" (this study's
} 
government officials, journalists, members of the nobility and the Court, and reached very close to the King. ${ }^{45}$

To maintain this clientele, Tanlongo went as far as falsifying the books of the bank and engaged in other irregular and, often, illegal, operations. He raised funds by issuing notes beyond the legal limit, covered shortfalls of cash through fictitious checks and loans, forged his bank's banknotes, allowed unauthorized overdraft on bank accounts, and engaged in a series of risky investments. All this was perpetrated by violating internal and statutory governance rules, centralizing operational decisions and limiting the information shared with the bank's shareholders and governing bodies. ${ }^{46}$

As a result, between 1882 and 1892, the bank more than doubled its credit to private borrowers, mainly in the form of short-term promissory notes (cambiali), the so-called "portfolio," that were frequently rolled over, were not called upon maturity, or were even issued with an open-ended maturity. This credit expansion was financed by an equivalent increase in the note circulation (Figure 10), that largely exceeded the legal limits and was not backed by a corresponding increase in capital or cash reserves (Figure 11).

Figure 10. Banca Romana: Circulation, Portfolio, and Private Sector Credit, 1870-1893 (million lire)

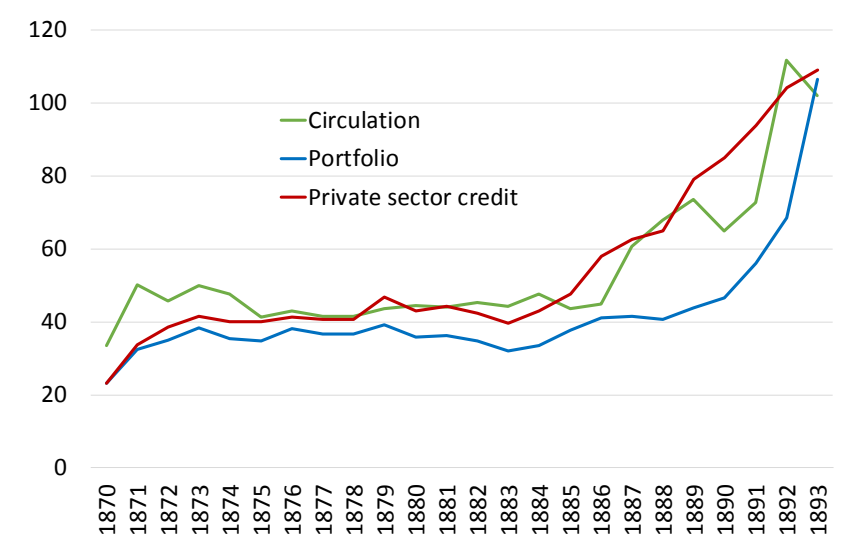

Source: de Mattia (1967)

\footnotetext{
translation; emphasis added). It should be noted that 1876 precedes Tanlongo's appointment as Governor and marks the rise to power of the Historic Left.

${ }^{45}$ Urbano Rattazzi Jr., Minister of the Royal Household, was one of Tanlongo's clients (Duggan, 2002).

${ }^{46}$ Biagini (1889); Finali Report (as quoted in Corriere della Sera, March 21, 1893, and di Nardi, 1953); Magrì (1993).
} 


\section{Figure 11. Banca Romana: Selected Balance Sheet Items, 1870-93 (million lire)}

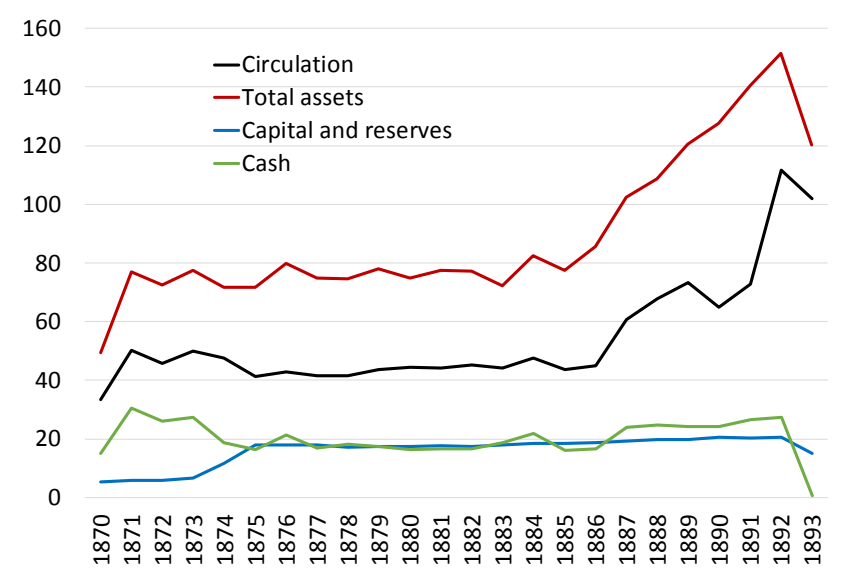

Source: de Mattia (1967)

The financial stability indicators of the bank thus deteriorated rapidly. Between 1882 and 1892, capital declined from 23 percent of assets and 33 percent of note circulation, to 13.5 percent of both, while cash declined from 26 percent of assets and 30 percent of short-term liabilities to 18 -22 percent (Table 1). ${ }^{47}$ In other words, the bank became less liquid and (compared to the growing size of its balance sheet) less capitalized.

These problems were not unique to Banca Romana, but were particularly severe at this bank (especially after 1889), where irregularities and fraud occurred on a large scale. The BNR and Banca Nazionale Toscana also experienced a marked decline in the capital-asset ratio between 1882 and 1892 (Table 2); unlike Banca Romana, however, these banks maintained a strong cash coverage of the circulation even after 1887 (Table 3). At BNR, this was helped by the increasing use of other forms of funding, such as the placement of mortgage-backed securities (cartelle di credito fondiario).

\footnotetext{
${ }^{47}$ A capital-asset ratio of 13.5 percent (not weighted for risk) may appear large today but was rather low for the standards of the time. Around 1890, the average capital-asset ratio of U.S. banks was about 25 percent (Allessandri and Haldane, 2009), and that of German banks was close to 35 percent (Buch et al., 2014); according to Jordà et al. (2017), in the same year the average capital ratio was about 25 percent in a group of 17 countries, including Italy, and a little below 20 percent in Italy (including commercial banks and other nonissuing entities). The ratio was lower (15 percent) among U.K. banks (Alessandri and Haldane, 2009), but in the latter, under "a regime of extended liability... shareholders were liable for an additional fixed level of reserve capital in the event of stress or bankruptcy," that brought their effective capital buffers to about 50 percent of assets (Haldane, 2012). It should also be noted that the need for capital buffers was particularly strong in the case of issuing banks, whose distress could cause a loss of confidence on the currency and impair the payments system.
} 
Table 1. Banca Romana: Selected Financial Stability Indicators, 1877-92 (percent)

\begin{tabular}{|c|c|c|c|c|c|}
\hline & 1877 & 1882 & 1887 & 1889 & 1892 \\
\hline Capital/asset ratio & 24.1 & 22.7 & 18.6 & 16.5 & 13.5 \\
\hline Capital on circulation & 36.1 & 33.1 & 24.7 & 20.4 & 13.4 \\
\hline Cash holdings on circulation & 40.7 & 36.9 & 39.6 & 32.8 & 24.5 \\
\hline Cash on total assets & 22.6 & 21.6 & 23.5 & 20.0 & 18.1 \\
\hline Liquid assets ${ }^{48}$ on total assets & 22.6 & 28.3 & 40.6 & 44.4 & 37.9 \\
\hline Cash on short-term liabilities & 33.0 & 30.2 & 30.5 & 25.6 & 21.7 \\
\hline $\begin{array}{l}\text { Liquid assets }{ }^{49} \text { on short-term } \\
\text { liabilities }\end{array}$ & 33.0 & 39.5 & 52.9 & 56.9 & 45.5 \\
\hline
\end{tabular}

Source: estimates based on de Mattia (1967).

Table 2. Italy: Capital-Asset Ratio of the Six Issuing Banks, 1877-92

\begin{tabular}{lccccc}
\multicolumn{7}{c}{ (percent) } \\
\hline & 1877 & 1882 & 1887 & 1889 & 1892 \\
\hline All banks (simple average) & 22.3 & 21.2 & 16.6 & 16.0 & 15.3 \\
BNR & 24.1 & 22.4 & 17.4 & 16.2 & 15.5 \\
Banco di Napoli & 16.6 & 16.6 & 14.2 & 14.6 & 14.9 \\
Banco di Sicilia & 13.6 & 16.8 & 14.6 & 15.7 & 14.6 \\
Banca Nazionale Toscana & 28.4 & 28.6 & 17.5 & 17.2 & 15.0 \\
Banca Toscana di Credito & 24.4 & 24.6 & 28.2 & 30.3 & 31.9 \\
Banca Romana & 24.1 & 22.7 & 18.6 & 16.5 & 13.5 \\
\hline
\end{tabular}

Source: de Mattia (1967).

Table 3. Italy: Cash Holdings in Percent of Circulation, 1877-92 (percent)

\begin{tabular}{llllll}
\hline & 1877 & 1882 & 1887 & 1889 & 1892 \\
\hline All banks (average) & 46.1 & 44.5 & 46.6 & 46.1 & 42.5 \\
BNR & 40.1 & 39.7 & 45.0 & 44.8 & 42.5 \\
Banco di Napoli & 68.7 & 57.8 & 47.1 & 45.3 & 42.1 \\
Banco di Sicilia & 58.5 & 66.5 & 67.6 & 74.2 & 60.3 \\
Banca Nazionale Toscana & 36.7 & 43.0 & 51.0 & 53.5 & 52.3 \\
Banca Toscana di Credito & 39.2 & 37.9 & 39.0 & 34.8 & 37.0 \\
Banca Romana & 40.7 & 36.9 & 39.6 & 32.8 & 24.5 \\
\hline
\end{tabular}

Source: de Mattia (1967).

\footnotetext{
${ }^{48}$ Cash plus active current accounts. It is not clear, however, to what extent active current account balances can be treated as liquid assets. In the case of Banca Romana, at least, they included overdrafts on passive accounts with uncertain repayment prospects (which increased significantly between 1882 and 1890) (Finali Report, as quoted in Corriere della Sera, March 21, 1893).

${ }^{49}$ Cash plus active current accounts.
} 
It is unclear to what extent this information may have been available to the general public at the time. Although the issuing banks were required by law to submit and publish, every ten days, financial statements that contained these and other data, ${ }^{50}$ this provision was at best implemented irregularly and with long delays. ${ }^{51}$

Although the weakest indicator at Banca Romana concerned its liquidity (and the crisis at the bank was initially spurred by liquidity concerns), its ultimate demise was not, however, caused by a funding crisis or "bank run," but by the insolvency caused by the erosion of its capital. ${ }^{52}$ In the midst of the crisis, a last-minute attempt to merge Banca Romana with three other issuing banks failed as it became evident that the bank was insolvent, leaving the government with no other option but to liquidate the bank. ${ }^{53}$

\section{The Crisis and the Bankruptcy}

The monetary expansion encouraged by the government failed to promote an acceleration of growth; instead, together with recurrent government deficits (Figure 12), it put pressures on the exchange rate, compromising convertibility and contributing to a slowdown and eventual reversal of capital flows. The lira-franc exchange rate depreciated marginally between 1883 and 1887-89 (presumably still within the "gold points"), but after 1887 the lira was convertible de jure but not de facto, as the issuing banks posed increasingly stronger obstacles to actual requests of conversion, and their bills started to trade at a discount (agio) on gold and silver. Net capital flows remained positive until 1890 but peaked in 1887 and declined rapidly thereafter. Around $1886-87$, both the credit and real cycles peaked, starting a downturn that would lead to the crisis of 1889-92 (Figure 13).

\footnotetext{
${ }^{50}$ Law of April 30, 1874 No. 1920, Art. 28; Royal Decree of January 21, 1875 No. 2372 Art. 21 and 22.

${ }^{51}$ For instance, the financial statement for Banca Romana as of December 10, 1884, was published in the Gazzetta Ufficiale del Regno d'Italia on December 31, 1884, p. 5967. Other statements were probably published but could not be found through a random search.
}

52 Many funding crises spurred by liquidity concerns can ultimately be retraced to doubts about solvency (see for instance, Admati and Hellwig, 2013). In the case of Banca Romana, before the crisis erupted into the open, in the absence of timely published financial statements, the public was concerned that its rapidly increasing note circulation was covered by increasingly less liquid assets (in itself, a liquidity issue), but there may also have been doubts that the deteriorating quality of its loan might have weakened its capital buffers (as it actually did). The insolvency of the bank emerged clearly only as a result of the investigations.

${ }^{53}$ As in other crisis situations, the distinction between liquidity and solvency issues became blurred as it became clear that all the issuing banks - and not only Banca Romana - were saddled with long-term assets

("immobilizations") that could, in principle, be recovered in the long term, albeit at an uncertain rate, but whose earlier liquidation would entail significant losses. In these conditions, a low liquidity rate was treated as a weak solvency indicator even if the net present expected value of a bank's assets might have exceeded that of its liabilities. 
The first strains appeared around 1887, when Italy broke commercial relations with France (Figure 14). ${ }^{54}$ In response, French capital flowed massively out of the country, straining the financial position of the banks and bringing the money expansion to a halt (Figure

15). These difficulties were compounded by a concomitant slowdown in construction, as the real asset bubble, no longer supported by incoming flows of funds, started to deflate (Figure 8). These developments, accompanied by a weak performance in agriculture, further weakened the balance sheet of the banks, which were saddled with poor-quality long-term loans and unable to roll over their short-term funding.

\section{Figure 12. Italy: Fiscal Balance, 1861-1913 (percent of GDP)}

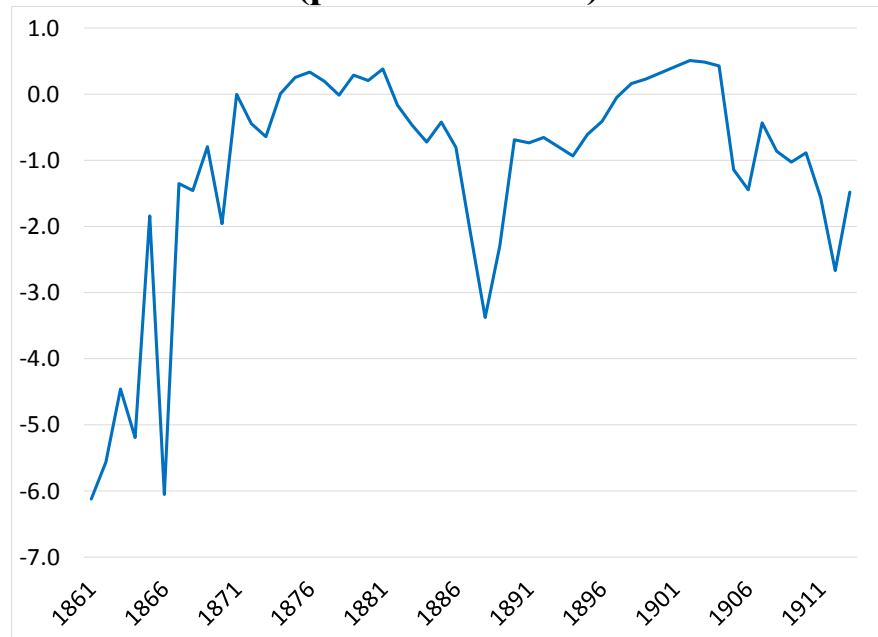

Sources: estimates based on Spinelli and Fratianni (1991) and ISTAT/Bank of Italy.

\section{Figure 13. Italy: Growth and Credit Cycles, 1874-93}

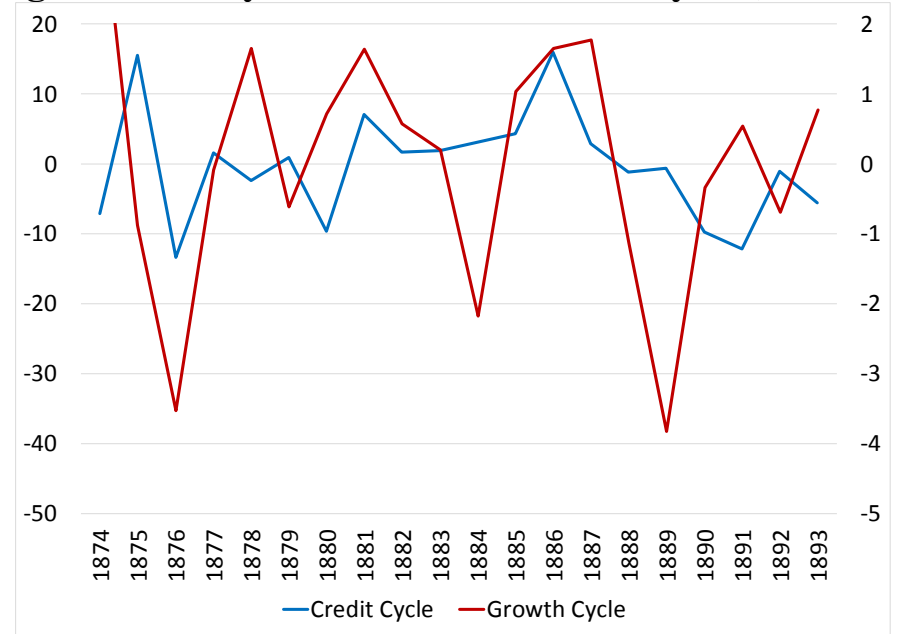

Sources: estimates based on ISTAT/Bank of Italy data. ${ }^{55}$

\footnotetext{
${ }^{54}$ They would resume in 1898.

${ }^{55}$ Real annual growth rates of GDP and deposit bank loans, in percent. The figure shows the cyclical component of both series, measured as the percentage point deviation from a trend estimated by applying the HP filter.
} 
Figure 14. Italy, Exports, 1881-90

(million lire)

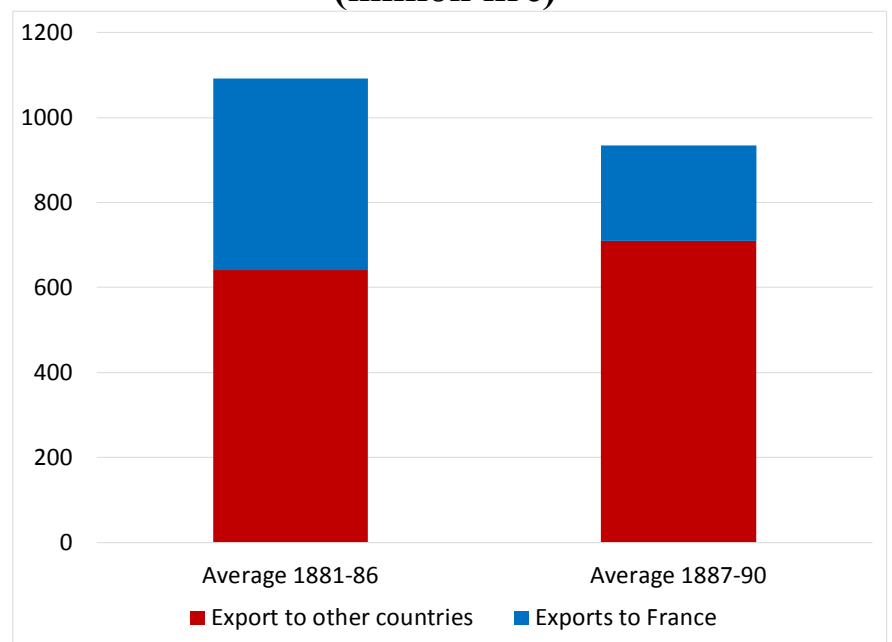

Source: ICS (1958).

Figure 15. Italy: Annual Rate of Money Growth, 1874-93 (percent)

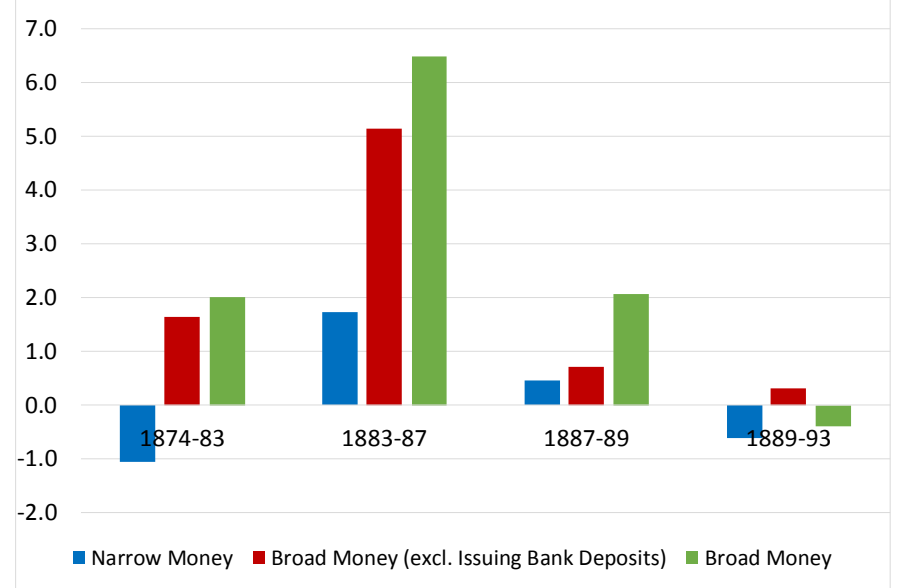

Sources: ISTAT and Bank of Italy.

These mounting strains are reflected in the movements in short-term interest rates. After 1886, the average rate on short-term bank loans (the most variable and, hence, informative rate indicator in this period) started to rise, ${ }^{56}$ signaling that, while domestic demand for funds remained strong, their supply from foreign sources was weakening (Figure 16). ${ }^{57}$ The interest

\footnotetext{
${ }^{56}$ It had remained constant at around 5.5 percent for two decades and declined slightly after the resumption of convertibility.

${ }^{57}$ Having reached their legal limit on circulation and thus being unable to expand their credit further, the issuing banks increased their lending rates from 4.5 in September 1886 (5 percent in the case of Banca Romana) to 5.5 percent in January 1887 (de Mattia, 1967).
} 
rate differential vis-à-vis the London market widened markedly until 1889, partly reflecting efforts to contain the depreciation of the lira produced by the agio on its banknotes. ${ }^{58}$

Faced with the risk that a banking crisis could provoke widespread bankruptcies, unemployment, and other social problems (the closure of a construction company in 1889 had spurred riots in Rome), and pressed by politicians with personal stakes in banks and real estate, the government urged the issuing banks to step in (Figure 17) and provide relief to the deposit banks in difficulty ${ }^{59}$ while allowing them, through a mix of forbearance and regularizations, to expand the circulation beyond the initial legal limits. This additional credit expansion, of course, fueled additional speculation and further weakened the quality of the banks' portfolio.

Figure 16. Italy: Average Interest Rate on Short-Term Bank Loans, 1874-98 (percent)

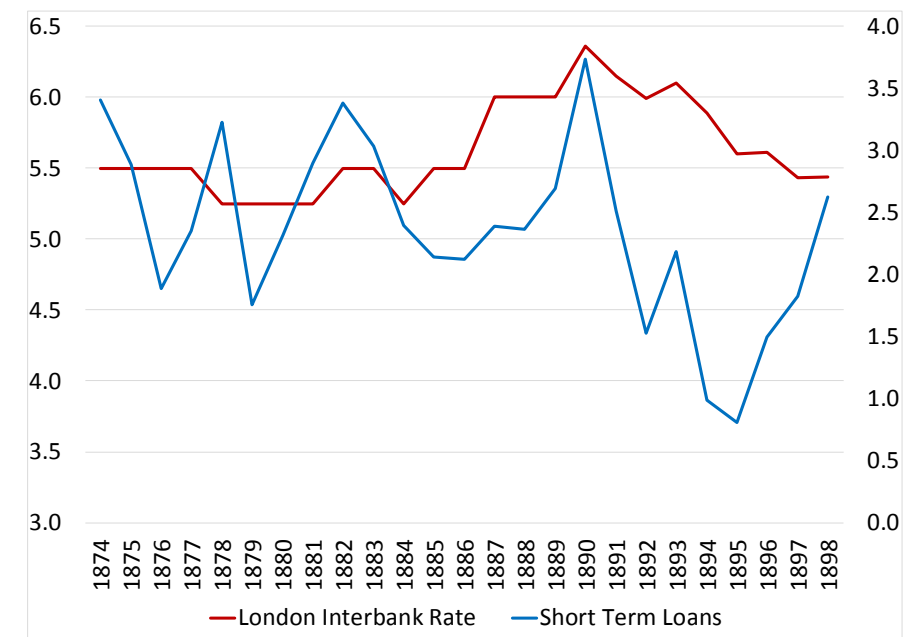

Sources: Bank of Italy; NBER.

\footnotetext{
${ }^{58}$ This consideration was explicitly mentioned by the BNR Governor, Giacomo Grillo, in his discussions with the bank's Board of Directors, for instance, in April 1885 (Confalonieri, 1974, p. 100). Differentials narrowed briefly around 1890 as rates in the London market peaked, but then widened again despite the decline in Italian interest rates, as credit and monetary conditions in Italy became tighter during the crisis.

${ }^{59}$ The most prominent interventions were the government-sponsored rescue by BNR of Impresa dell'Esquilino, a real estate company, and Banca Tiberina, a commercial bank (in whose rescue Banca Romana was also involved), both of which had strong interests and exposure to real estate in Rome and whose collapse risked to bring down other commercial banks, most notably in Turin, such as Banca di Torino and Banco di Sconto e di Sete: see for instance Confalonieri (1974) and Negri (2003).
} 
Figure 17: Italy: Average Annual Increase in Bank Loans by Type of Bank, 1874-93 (percent)

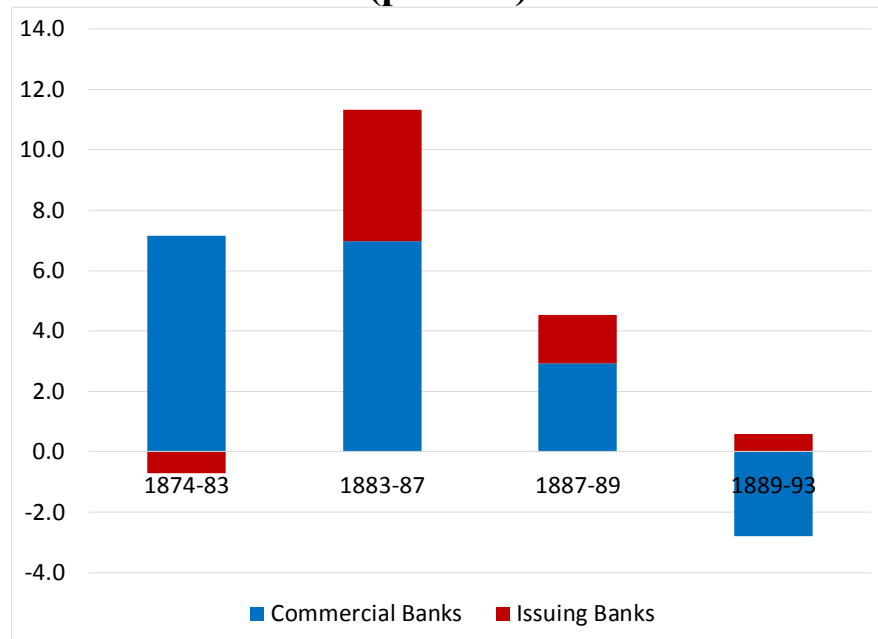

Sources: ISTAT and Bank of Italy.

It should be noted that Italy was not the only country to experience financial strains in this period. In Argentina (where, as in Italy, more than one bank had the privilege to issue banknotes), significant capital inflows between 1883 and 1889 financed large fiscal deficits and a credit expansion, fueling an unsustainable economic boom that turned into a crisis once foreign investors started pulling out of the country in 1889 (della Paolera and Taylor, 2001). ${ }^{60}$ In Australia, government borrowing from London fueled a speculative building boom in Melbourne that started in 1886 and came to an end in 1891, leading to bank failures and to a prolonged contraction of GDP (Goodhart and Delargy, 1998). Following an investment boom in railways, the U.S. experienced a prolonged loan contraction after 1890 . High interest rates led to a fall in stock prices and to an economic downturn; the good harvest of 1891 provided some temporary relief, but strains intensified with the bad harvest of 1892 leading to the collapse of several banks (ibid.).

In 1890 bank credit in Italy reversed its upward trend and started to decline by about 2 percent a year until 1898 (Figure 18). Prompted by the government, the issuing banks continued to expand their credit (but at a reduced pace) until 1893 by enlarging their circulation, but this opened the door to abuse and merely postponed the moment of reckoning, allowing the imbalances to increase in the meantime.

\footnotetext{
${ }^{60}$ See also Goodhart and Delargy (1998). The crisis in Argentina led to the collapse of Baring Brothers bank in London, which was salvaged by an intervention of the Bank of England. Baring's collapse led, in turn, to a retrenchment of capital from the "periphery" toward the "center," which caused financial strains in a number of countries, including the U.S. (Goodhart and Delargy, 1998) and various Latin American countries (Mitchener and Weidenmier, 2007).
} 
Figure 18. Italy: Average Annual Growth in Bank Loans, 1974-1913 (percent)

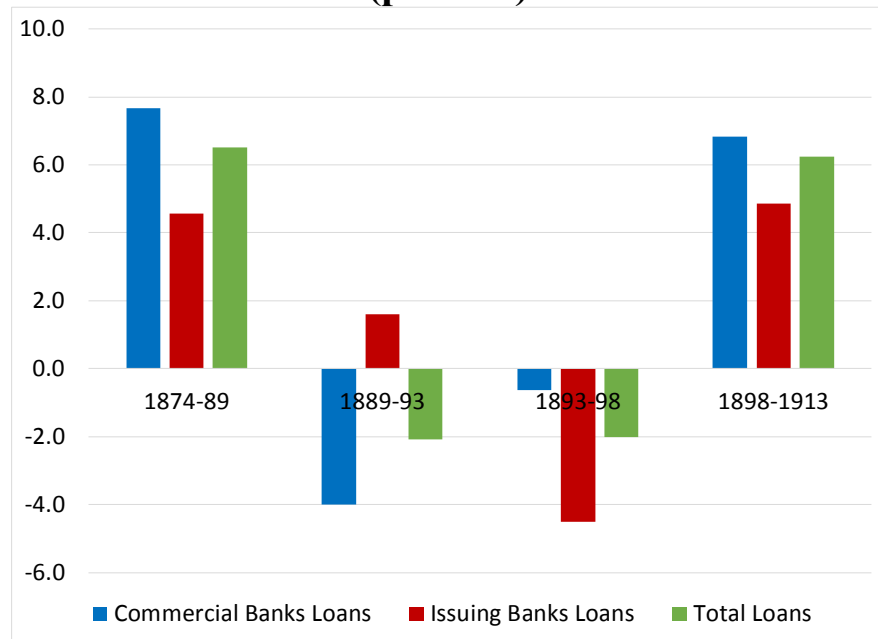

Sources: ISTAT and Bank of Italy.

Amid widespread rumors of an excessive note circulation and mounting concerns about the solvency of what was rightly perceived as the weakest issuing bank, Banca Romana, in April 1889 the Minister of Agriculture (responsible for bank surveillance), Luigi Alfonso Miceli, launched an inquiry into all six issuing banks. ${ }^{61}$ The investigation, led by Senator Giacomo Giuseppe Alvisi with the support of a top Treasury official, Gustavo Biagini, uncovered severe financial problems and irregularities at Banca Romana, including an unauthorized excess circulation of 25 million lire, irregular overdrafts, and a cash shortage of 9 million clumsily disguised through an illegal, unrecorded production of bank notes (Box 1). Most of the bank's assets appeared to consist of low-quality, unsecured personal loans whose systematic "evergreening" disguised their effective nonperformance. In fact, the managers of the bank had engaged in a vast asset-stripping operation, using the funds administered by the bank to make transfers (improperly disguised as loans) to politicians and other powerful supporters. To cover this operation, they had committed a variety of violations ranging from breaking reserve requirements and trespassing circulation limits to the outright falsification of documents (e.g., opening fictitious accounts). Other issuing banks, most notably Banco di Napoli, had performed similar irregularities, but on a smaller scale.

\footnotetext{
${ }^{61}$ Royal Decree of April 30, 1889. According to Macrì (1993), Poddi (2016), and Quilici (1935), the inquiry may have been launched on behalf of the prominent politician of the Left, the Hon. Giovanni Nicotera, against the Managing Director of Banco di Napoli, Girolamo Giusso, and covered all six issuing banks in order to preserve the appearance of impartiality.
} 


\section{Box 1. Banca Romana: Irregularities Highlighted by the Alvisi Investigation ${ }^{1}$}

- About 49 million lire in cash and securities (including 7 million of reserves) are under the sole control of the Cashier;

- The required monthly verification of the amount of cash in vaults has not been implemented for a long time;

- The templates and paper for the banknotes are held in a safe at the sole disposal of the Governor;

- A large share of assets consists of loans that are nonperforming or regularly rolled over, including promissory notes accepted with long maturity or no indication of maturity;

- Active current accounts are often used to finance long-term investments;

- Guarantees on loans are inadequate, nonexistent, or poorly documented;

- The banknotes in circulation exceed the authorized limit by 25 million;

- There is a 9 million cash shortfall which has been covered with illegally produced notes (whose production was not officially recorded);

- Loans have been extended to insiders, including the Governor (1.2 million) and the Chairman of the Board of Internal Auditors (3 million);

- Personal loans have been extended without the authorization of the Discount Committee;

- All operating decisions are taken solely by the Governor.

${ }^{1}$ Source: Biagini (1889).

This evidence seems to be sufficiently serious to initiate criminal proceedings and spur a major political debate, but the government took no action, except to cover up the scandal. Commendator Tanlongo, questioned by the Minister, denied all allegations of misconduct and, by securing a short-term loan from the BNR branch in Pisa, concealed the cash shortfall at a follow-up onsite visit. ${ }^{62}$ Commendator Antonio Monzilli, Division Chief at the Ministry of Agriculture, planted in the investigative team by Minister Miceli possibly for this purpose, ${ }^{63}$ provided an alternative account ${ }^{64}$ - based on more partial information - that presented a much rosier picture. On this basis the Minister omitted to present the report to Parliament. Senator Alvisi's efforts to have a discussion tabled on the Senate's floor came to no avail; in 1891, the then Prime Minister, Marques di Rudinì, even classified the report as a state secret - by claiming that it could compromise the confidence of the public.

The politicians were probably concerned that higher transparency would unveil their, at best, questionable role in the crisis. Moreover, they were continuing to benefit from Tanlongo's

\footnotetext{
${ }^{62}$ Atti Parlamentari (1993b), p. 6363; Poddi (2016); Quilici (1935).

${ }^{63}$ Macrì (1993); Poddi (2016).

${ }^{64}$ A formal report of the investigation had been issued by Senator Alvisi to the Minister on August 30, 1889; Commendator Monzilli presented an alternative report on February 27, 1890 (Mordini et al., 1893, pp. 6381-2). In an interview published by Corriere della Sera on January 25, 1893, Miceli still claimed that in Monzilli's report "the true state of things is described without exaggeration."
} 
largesse. After Alvisi's inquiry, Tanlongo actually stepped up his extension of favors and "loans" to powerful connections, possibly in an attempt to secure protection from the fallout of the inquiry. He was helped by a law passed in June $1891,{ }^{65}$ which raised the circulation limit to four times the capital. Despite this easing of rules, between Alvisi's investigation and the following visits by examiners (in 1893) the unauthorized circulation of Banca Romana almost doubled, rising to about 0.5 percent of GDP, and there was even a (botched) attempt to put in circulation some 41 million lire of fake (duplicated) notes. In 1892, the bank (which, based on Alvisi's findings, was already insolvent) opened two new branches, in Milan and Venice. ${ }^{66}$

Meanwhile the strains were becoming evident. In 1892 a court in Turin upheld the issuing banks' right to resist the conversion of their notes into metal currency, giving legal sanction to the de facto suspension of convertibility. In the midst of these troubles, in November 1892, the Prime Minister, Giovanni Giolitti, proposed the nomination of Tanlongo to the Senate ${ }^{67}$ and appointed him (in his role as President of the Chamber of Commerce of Rome) to the committee in charge of monitoring public debt. ${ }^{68}$ The fox was in charge of the hens.

The veil of secrecy that surrounded the Alvisi Report was eventually broken by a series of unexpected and even fortuitous events. On November 24, Senator Alvisi died, leaving a copy of the report of his investigation in the hands of a group of economists of the radical opposition, including a deputy, the Hon. Napoleone Colajanni. ${ }^{69}$ A few days later, in December, the government submitted to Parliament a controversial bill that would, effectively, prolong the monopoly of the issuing banks for another six years; in response, on December 20, Colajanni intervened in the Chamber denouncing the irregularities exposed in trhe Alvisi report and attacking the government for not publishing it. The government was forced to withdraw the bill and replace it with a mere three-month extension of the legal tender (due to expire at the end of the year) (Appendix II).

\footnotetext{
${ }^{65}$ Law of June 30, 1891 No. 314. Another Law passed on the same day, No. 313, increased the circulation tax from 1 to 1.44 percent.

${ }^{66}$ Grapanzano and Giulianini (2010).

${ }^{67}$ According to Duggan (2002), Tanlongo's appointment had been solicited by the King out of concerns that revelations about the situation at Banca Romana may raise a scandal that could involve the Royal Family. Unlike his two predecessors (who had resisted this suggestion) Giolitti proved more pliable to the King's exhortations. Quilici (1935), on the other hand, is more convinced that Giolitti proposed Tanlongo's appointment to reward him of the financial support he provided to the government party during the elections (p.74). What is clear is that Tanlongo's name was added to the list by Giolitti himself, at the last moment and in his own handwriting, on his own initiative and not as an endorsement of the proposal of some minister (see also Corriere della Sera, January 22, 1893; and Manacorda, 1968).

${ }^{68}$ Royal Decree of December 18, 1892; see Corriere della Sera, December 22, 1892.

${ }^{69}$ A detailed account of how Colajanni got hold of a copy of the report is found in Manacorda (1968).
} 
The cat was out of the bag. While current and former ministers tried to dismiss the revelations as the exaggeration of a comparatively minor problem, the scandal received much attention in Parliament and in the press, leading to a 5 percent decline in the price of the shares of Banca Romana (Figure 19). The current and two former Prime Ministers, called into question, ${ }^{70}$ argued that (a) the irregularities uncovered by the Alvisi inquiry were not as severe as suggested by Colajanni (whose remarks were based on the first impressions of the investigators, that had been promptly corrected upon further examination); (b) the Minister responsible for Bank surveillance (Miceli) had immediately taken the necessary remedial actions; (c) for these reasons, the cabinet had not given much importance to the report (Giolitti, Treasury Minister at the time of the inquiry, even claimed that he had never read it); and (d) publishing the report could jeopardize the "national credit" (meaning both confidence and financial stability), especially in that period of economic and financial strains. ${ }^{71}$ The opposition - and part of the press - did not buy into these arguments, ${ }^{72}$ but they served as an excuse for the Parliamentary majority, some of whose members had received funds from Banca Romana, to reject the calls for a parliamentary investigation. The government agreed instead to launch a new ministerial inquiry, led by the President of the Court of Accounts, Senator Gaspare Finali. ${ }^{73}$

Finali's investigation not only confirmed the irregularities denounced in the Alvisi report, but uncovered additional violations both at Banca Romana and at Banco di Napoli, as well as political-administrative connections. ${ }^{74}$ This time $^{75}$ the information was passed on to the

\footnotetext{
${ }^{70}$ Francesco Crispi, who had been Prime Minister at the time of the Alvisi investigation and until February 1891; Antonio Starabba, Marques di Rudiní, who succeeded Crispi; and Giovanni Giolitti, who succeeded Di Rudiní in May 1892.
}

${ }^{71}$ Atti Parlamentari (1892). Crispi, who was Prime Minister at the time of the investigation, claimed later (on February 22) that he had deemed appropriate to postpone any criminal investigations after the reforms of the banking sector had put the country's financial system on a more stable footing; his reform proposals, presented in the fall of 1890, had been set aside after his resignation in January 1891 (Atti Parlamentari, Camera dei Deputati, XVIII Legislatura, Ia. Sessione, Discussioni, “Tornata di mercoledì 22 febbraio 1893,” resoconto stenografico, p. 1621).

${ }^{72}$ With the possible exception of the risk of compromising the (domestic and foreign) public's confidence in the Italian banking sector (which had however already been damaged by mounting rumors and might even have been strengthened by candid communications on the part of the authorities). During the parliamentary debate on February 22, 1893, Crispi read notes of a meeting with Giolitti on June 14, 1890, in which the latter allegedly had noted that the facts uncovered by the then ongoing Alvisi investigations offered "material for the [criminal] Court of the Assizes." (Atti Parlamentari, Camera dei Deputati, XVIII Legislatura, Ia. Sessione, Discussioni, “Tornata di mercoledì 22 febbraio 1893," resoconto stenografico, pp. 1620-1).

73 The investigation was launched by Royal Decree on December 30, 1892 and was instructed to produce a report by the end of February 1893.

${ }^{74}$ Corriere della Sera, March 21, 1893.

75 January 18, 1893. 
judiciary, which ordered the arrest of Tanlongo ${ }^{76}$ and of the bank's Cashier, Cesare Lazzaroni. During interrogations, Tanlongo declared to have lent large sums to several politicians, including the current and former Prime Ministers, Giolitti and Crispi, who denied the allegations. Besides Tanlongo and Lazzaroni, their respective sons, Pietro and Michele, were also arrested, together with Commendator Monzilli, the author of the (misleading) alternative report for the 1889 Alvisi investigation. ${ }^{77}$

The debate in Parliament resumed after the Christmas break on January 25, with fifteen questions to the government on banking issues; Giolitti unveiled the key preliminary findings of the new investigation, but continued to resist calls for a Parliamentary inquiry (now supported even by his predecessor, Marques di Rudiní) arguing that it would interfere with the judicial investigation. ${ }^{78}$ The Chamber agreed to postpone the discussion and, on February 3 , allowed the magistrates to proceed against the Hon. Rocco de Zerbi, hitherto a highly respected deputy, accused to have received more than half a million lire from the bank in exchange for supporting it in Parliament. ${ }^{79}$ Meanwhile, the stock market price of the shares of Banca Romana collapsed (Figure 20); by the end of January, the shares already traded at less than half their average price in 1892.

\footnotetext{
76 Tanlongo, who at the time was 73 year old, was initially placed under house arrest for health reasons and was taken to jail on January 24. His appeal to parliamentary immunity was dismissed as his appointment to the Senate, announced officially on November 21, had not been ratified by that Chamber. The nomination was then revoked by Royal Decree, on the initiative of Prime Minister Giolitti. (Quilici, 1935; Corriere della Sera, January 20, 21, and 25, 1893; Gazzetta Ufficiale del Regno d'Italia, February 21, 1894, p. 719).

${ }^{77}$ Criminal charges were also raised against some administrators of other issuing banks, such as the Director General of Banco di Napoli, Vincenzo Cucciniello (arrested on January 22: Corriere della Sera, January 23, 1893), and the Director General of Banco di Sicilia, Giulio Benso Sammartino, Duke della Verdura (Corriere della Sera, March 29, 1893)..

${ }^{78}$ Atti Parlamentari (1893a). Undeterred by the new evidence, Giolitti went as far as to claim (raising the deputies to laughter) that, since Miceli had declared that the irregularities uncovered by the Alvisi inquiry three years earlier had since been rectified, that inquiry could not be used as a guide for the new investigation.

${ }^{79}$ De Zerbi died of a heart attack on February 20 (Corriere della Sera, February 21, 1893). He was not the only person to die as a result of the scandal; Commendator Emanuele Notarbartolo, who as Director General of Banco di Sicilia had corrected the mismanagement of his predecessors, was assassinated on February 1, before he could be heard by the investigators (Corriere della Sera, February 3, 1893; Quilici, 1935; Macrì, 1993).
} 
Figure 19. Banca Romana: Share Price at the Rome Stock Exchange, December 1892

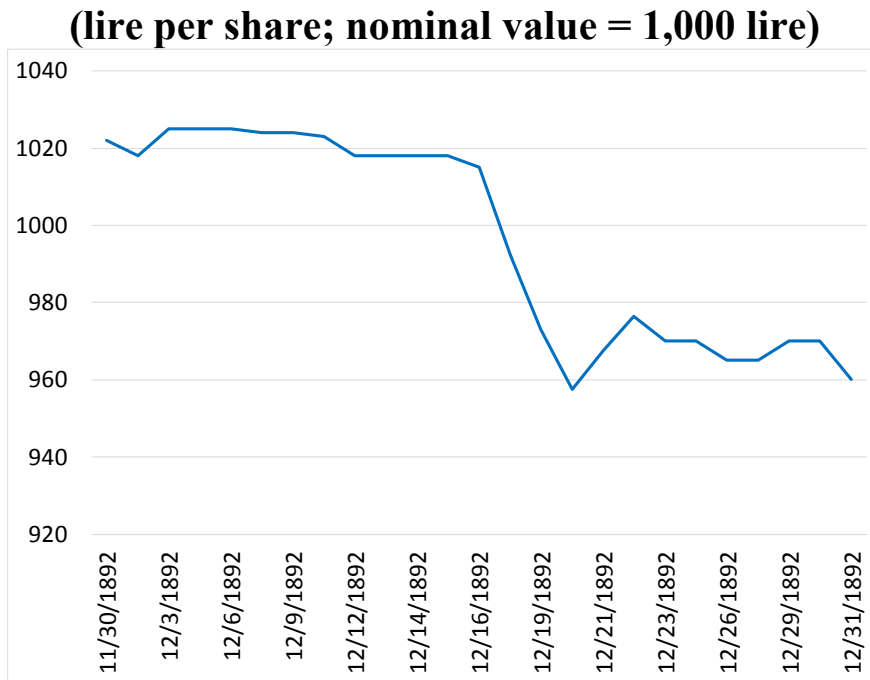

Source: Gazzetta Ufficiale del Regno d'Italia.

Figure 20. Banca Romana: Share Price in the Rome Stock Exchange, JanuaryFebruary 1893

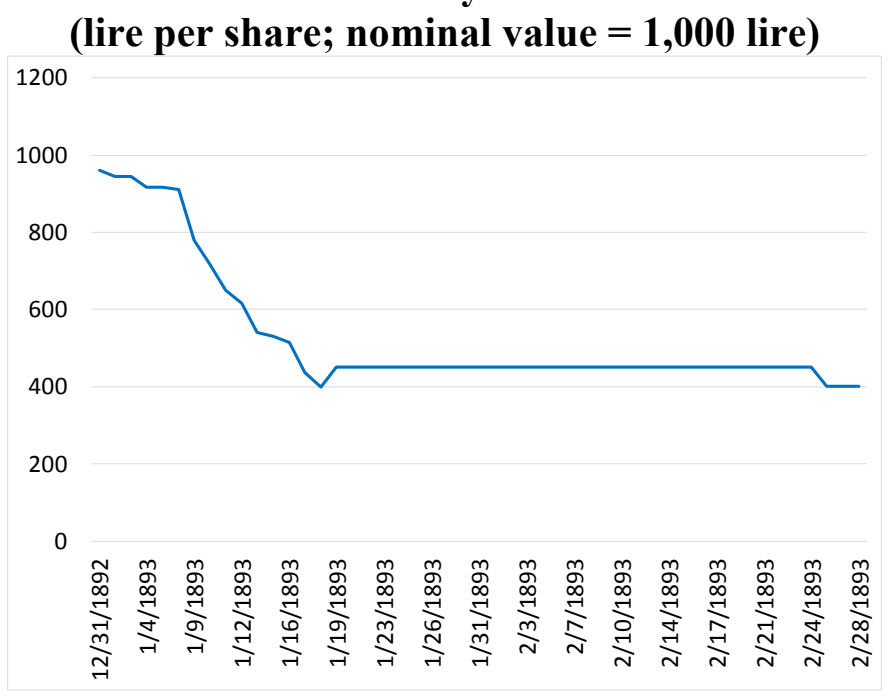

Source: Gazzetta Ufficiale del Regno d'Italia. 
On March 9, Finali presented his report to the Prime Minister: Banca Romana had issued notes for 137 million lire, 65 million above the regulatory limits, ${ }^{80}$ and had a cash shortfall of 28.6 million. ${ }^{81}$ Its loan portfolio included nonsecured and nonguaranteed loans as well as loans of questionable quality to construction and real estate companies, and a large share of its active current accounts (that amount in total to 53.1 million) were, in large part, illiquid or fictitious. The bank's immobilizzazioni (highly illiquid long-term assets) amounted to 18.2 million, and its non-performing loans (NPLs) to 16 million (compared with a capital of 15 million). In summary, its problem loans were such that "not only [the bank had] left there all its capital, but present[ed] a situation that [could] be liquidated only [by incurring] strong losses that it [could not] cover." 82 In other words, the bank was bankrupt. Problems were also found at other issuing banks, most notably at Banco di Napoli (including a 2.4 million lire cash shortfall) and Banco di Sicilia; altogether, their long-term assets (immobilizzazioni), which they were not supposed to acquire, amounted to 200 million, and their NPLs to 62 million (133 million including renewable promissory notes). The Finali Report also included a separate list (which was not made public) of people who had received money from the investigated banks, or had with them outstanding nonperforming obligations. ${ }^{83}$

These revelations finally induced the Chamber of Deputies, on March 21, to launch a parliamentary inquiry, which was assigned to a "Committee of 7" led by the Hon. Antonio Mordini; meanwhile, the scandal became a prominent issue in the political duel between Crispi and Giolitti, who traded reciprocal accusations of involvement and cover-up. ${ }^{84} \mathrm{On}$ November 23, 1893, the Mordini committee presented to the Chamber a report that documented how various deputies, government officials, and journalists (the report did not cover senators or members of the Royal Family) had obtained money from the bank as a result of their position or by promising, or granting, favors (Box 2). The Committee also highlighted how Crispi and Giolitti, in their respective roles as Prime Minister and Treasury Minister, had been aware of the results of the Alvisi inquiry and should not have concealed them from the public and, least of all, from the parliamentary committee in charge of the

\footnotetext{
${ }^{80}$ The excess circulation started as early as 1883 , and was concealed by recording fictitious deposits among its liabilities; in an attempt to cover the cash shortfall during the inspection, fictitious checks had been drawn from the accounts of various people, including the Governor and the Cashier of the bank (Corriere della Sera, March 21, 1893; Quilici, 1935).

${ }^{81}$ The Finali investigation also discovered that, starting in 1890, Tanlongo and his cashier even made a botched attempt at forgery, duplicating about 41 million lire of notes by replicating the serial numbers used 20 years earlier (under the Pope's jurisdiction). The notes, printed in London by the firm H.C. Sanders and Co., were signed by Tanlongo at home overnight, with the help of his son and of the Bank's Cashier, using the stamps of three former censors of the Bank. Serious as this violation was from a legal perspective, it was economically inconsequential, as the quality of the forgery was so bad that it was easily, if fortuitously, detected. A bank employee reported it to the managers, forcing them to destroy the notes before they were put in circulation (Conterio, 2011; Corriere della Sera, March 21, 1893; di Nardi, 1953; Grapanzano and Giulianini, 2010; Macrí, 1993; Poddi, 2016; Quilici, 1935).

${ }^{82}$ Finali Report, quoted from di Nardi (1953); this paper's translation.

${ }^{83}$ Corriere della Sera, March 21, 1893; di Nardi (1953).

${ }^{84}$ Duggan (2002); Macrì (1993); Manacorda (1968).
} 
banking sector reform bill; moreover, it disapproved the "lack of consideration" paid to the results of the Alvisi inquiry when proposing Tanlongo's appointment to the Senate. The Committee then recommended that all the staff of the Ministry of Agriculture in charge of bank surveillance (by now, jointly with the Treasury) should refrain from requesting loans from the banks.

\section{Box 2. Selected Issues Deplored or Disapproved by the Mordini Committee ${ }^{1}$}

\section{Concerning deputies:}

- One deputy continued to borrow from the Bank while serving as junior minister of Agriculture (therefore responsible for its surveillance)

- One deputy in arrears on a loan to Banca Romana had served in the parliamentary committee charged with examining a Bill to reform the issuing banks;

- One deputy with outstanding balances due to the Bank had written letters to its Governor;

- Another deputy, who had discussed banking sector reforms with the Governor, had written a letter to the latter soliciting the disbursement of loans already pledged that would have been used to publish a newspaper;

- Deputies serving as Minister and junior minister of Agriculture had recommended the provision of loans from Banco di Sicilia to private citizens;

- Two deputies who served on the Board of Directors of Banca Romana had not exerted due diligence in performing their functions;

- Two deputies who served as Ministers of Interior (Law and Order) and Agriculture had written letters urging the Governor to extend a 1.6 million lire loan to a person who had previously defaulted on a 3.4 million loan with another issuing bank;

\section{Concerning journalists:}

- Two journalists had accepted money from the bank to publish articles in favor of bank pluralism, and another journalist had maintained a large overdue position vis-a-vis the bank; another journalist had maintained overdue balances with the bank;

\section{Concerning civil servants:}

- A former Government Chief Accountant had kept overdue balances with the Bank and solicited loans on behalf of family members that engaged in speculative operations;

- A high official of the Ministry of Justice had sent repeated requests for his loan to be rolled over, promising the Governor that he would take care of an outstanding case concerning him;

- Two top government officials with large outstanding loans due to the bank, including a chief of cabinet of the ministry in charge of bank surveillance, had promised favors to the Governor;

The Committee also noted that a deputy had kept balances between 3.3 and 4.6 million lire, with 2.4 million overdue, during his term in office.

${ }^{1}$ Source: Atti Parlamentari (1993b).

The Prime Minister, Giovanni Giolitti, who had been Treasury Minister at the time of the Alvisi investigation and borrowed 70,000 lire from Banca Romana in September 1892, resigned on November 24. He was succeeded by Francesco Crispi, who had been Prime Minister at the time of the Alvisi investigation and had also received money from Banca Romana, and who promptly proceeded to classify as secret the list of the politicians and officials involved. Meanwhile the case in court proceeded but, amid strong political pressures 
and helped by the removal of some documents during the search of Tanlongo's house, all defendants were acquitted (after spending one year and a half in custody) on July 29, 1894. On December 11, 1894, Giolitti presented some of these (and other related) documents to the Chamber of Deputies, which published some of them, revealing to the general public more details on the involvement of politicians and journalists with Banca Romana and inducing the Prime Minister to close the parliamentary session and call early elections. ${ }^{85}$

\section{Resolution and Aftermath (1893-94)}

The irregularities uncovered by the Alvisi and Finali investigations had several economic implications. The most pressing was the need to reassure the public about the value of the currency, which was effectively nonconvertible and whose legal tender would expire at endMarch 1893. The government responded by instructing all its offices and cashiers to accept the notes of Banca Romana in payment at face value. Similar instructions were given to the branches of BNR - which also served as an agent of the Treasury - in the areas where Banca Romana notes were, or had been, legal tender; BNR was also "encouraged" not to spend these notes "whenever possible." The legal tender was then extended (as usual: see Appendix II) to end-June and, later, to end-August.

The broader issue of the resolution of Banca Romana was more complex. The bank's liquidity situation appeared much worse than expected, with a larger-than-authorized stock of short-term debt (deposits and banknotes payable on sight) covered by largely illiquid or nonperforming assets, and deteriorated further as depositors rushed to withdraw their funds. ${ }^{86}$ The bank's capital had been dissipated not only by the extension of nonsecured loans that were largely nonperforming, but also by the bank's exposure (both direct and indirect) to the real estate asset bubble. The other issuing banks (with the exceptions of the two Tuscan banks) also shared some of these problems, but their financial position was stronger.

The debate on the resolution of Banca Romana merged with the broader question of the reform of the banking system, that had lingered on the agenda for decades (Box 3). Indeed, the question of whether the authority to issue banknotes should be centralized into a single institution had been discussed since the unification of the country. On one side, free-market economists, fearing the adverse consequences of monopoly, argued in favor of plurality, using as a benchmark the Scottish and Irish (and sometimes the American) banking systems; they were supported by politicians representing powerful regional interests, which remained strong in a country that had been only recently unified. On the other side, the government, concerned about efficiency and about the support that could be gained from a single central bank, tended to lean in favor of unification. In the midst came the lobbying activity of the issuing banks themselves, which strove to preserve the status quo and acted (often jointly,

\footnotetext{
${ }^{85}$ Corriere della Sera published these documents on December 15, 1894. The documents also involved the Prime Minister, Crispi (who appears to have borrowed 90,000 lire in 1888, reduced to 55,000 on December 10, 1892), and his wife, Lina. The Crispis then sued Giolitti for defamation. Despite the scandal, Crispi obtained a large majority at the 1895 elections and was able to form his last cabinet, which lasted until March 1896.

${ }^{86}$ See for instance Corriere della Sera, January 15, 16 and 20, 1893.
} 
sometimes separately) to influence politicians and public opinion in favor of maintaining plurality (while preventing new entries). Even the BNR, which by virtue of its dominant position would have been the natural candidate to take the role of the single bank, was not an overly enthusiastic supporter of unification, which risked undermining its independence from the government (as eventually happened). ${ }^{87}$ For decades, the outcome of this debate was the persistence of an oligopolistic status quo, with reforms only at the margin. The question however kept re-emerging. ${ }^{88}$

\section{Box 3. Law Bills for the Reorganization of the Issuing Banks, 1864-941}

- Establishment of the Bank of Italy: submitted in April 1864; not discussed.

- Establishment of the Bank of Italy: submitted in March 1865; not discussed.

- Establishment of the Bank of Italy (No. 36): submitted in December 1865; approved by the Senate but not by the Chamber of Deputies.

- Organization of the issuing banks (No. 154): submitted in November 1883; not discussed

- Reorganization of the issuing banks (No. 12): submitted in November 1887; not discussed.

- Reorganization of the issuing banks (No. 125): submitted in June 1889; not discussed.

- Organization of the issuing banks (No. 73): submitted in November 1889; not discussed

- Reorganization of the issuing banks (No. 333): submitted in April 1992; not discussed.

- Reorganization of the issuing banks (No. 164): submitted in March 1993; approved by the Chamber of Deputies in July and by the Senate in August; became Law of August 10, 1893 No. 449.

- Reorganization of the issuing banks (No. 297): submitted in February and May 1994; approved by the Chamber of Deputies and by the Senate in June; became Law of July 22, 1894 No. 339.

${ }^{1}$ Source: de Mattia (1967).

As the crisis at Banca Romana broke out in December 1892, the Giolitti government encouraged merger negotiations amid the four joint-stock banks (the two Southern banks were non-profit legal entities), but Banca Romana was eventually excluded from the merger and put in liquidation, as BNR management became increasingly concerned about the Bank's parlous financial conditions (Negri, 2003), while Tanlongo resisted, to the end, all proposals to merge his bank with the others (Macrì, 1993). A convention for the merger between BNR and the two Tuscan banks, and a second convention between these three entities and Banca Romana for the liquidation of the latter, were signed on January 19. Their provisions were later incorporated, with some modifications, in the Banking Bill that was submitted to

\footnotetext{
${ }^{87}$ See Gigliobianco and Giordano (2010).

${ }^{88}$ Supporters of the "single bank" option were divided into those that favored a merger of the existing banks (or a phasing out of the authorization to the minor banks to issue banknotes) and those who promoted granting the monopoly of issue to a government-owned "state bank" to be established ex novo.
} 
Parliament on March 22 and approved during the summer after an intense debate in the Chamber. ${ }^{89}$

The new law (hereafter, the Law of 1893), based on a compromise but clearly shaped on the single bank model, provided for the establishment of a new institution to be called the Bank of Italy (Banca d'Italia), resulting from the merger of BNR with the two Tuscan banks. Banca Romana would be liquidated, and its assets and liabilities would be transferred to Bank of Italy, which would, in return, receive implicit subsidies in the form of a monopoly of issue for 20 years, a rebate on the circulation tax (from 1.44 to 1 percent), ${ }^{90}$ and the benefit of legal tender for its notes for 15 years. In response to strong demands from southern parliamentarians, the two Southern issuing banks, Banco di Napoli and Banco di Sicilia, were still authorized to issue banknotes, but under strict limits. Changes in the discount rate (the same for all three banks) had to be approved by the Government, banks had to comply with capital adequacy ratios, their operations were restricted to those explicitly mentioned in the law (which did not include long-term investments), the banks' top officials had to be approved by the Government, and government supervision was reinforced by tightening penalties and controls. Surveillance over the three issuing banks was to be carried out by the Minister of Agriculture jointly with the Minister of the Treasury. The law also formally provided for the restoration of convertibility, but deferred its implementation to a royal decree that was never issued. In practice, in the years following the reform, the new monetary anchor was not the exchange rate but the legal limits on money supply (i.e., circulation), which preserved some degree of flexibility (Gigliobianco and Giordano, 2010). ${ }^{91}$ The Law also authorized - but did not require - the Bank of Italy to outsource the liquidation of all or part of its long-term assets (including those acquired from Banca Romana) to a "bad bank," an option that the Bank of Italy preferred not to use in order to avoid incurring the losses associated with selling its assets at a discount.

The Law was criticized by free-market economists, who questioned in particular the validity of posing a double constraint on the circulation (capital and reserve requirements), the rigidity of the discount rate, and the effectiveness of government supervision compared to

\footnotetext{
89 The bill became the Law of August 10, 1893 No. 449, effective on January 1, 1894. It is also known as the Lacava-Grimaldi Law.

${ }^{90}$ This tax rebate was later strengthened with the Convention of November 28, 1896, ratified with the Royal Decree of December 6, 1896 No. 517 and with the Law of January 17, 1897 No. 9, which provided for gradual reductions of the tax rate up to 0.1 percent as the bank proceeded with the liquidation of its long-term assets.

91 This was not a monetary policy framework based on targeting monetary aggregates. The general framework remained the long-term restoration of convertibility at the initial parity under the gold (formally, bimetallic) standard; any deviations of the exchange rate from this long-term peg were considered to be temporary, although they could last for several years. Margins for flexibility existed mostly in the short term.
} 
market discipline. ${ }^{92}$ Other commentators saw the constraints on circulation as a second-best alternative to convertibility. ${ }^{93}$

The new law, coming at a time of global liquidity strains in the wake of the Barings debacle, ${ }^{94}$ was not sufficient to reassure investors, and the tensions on the (nonconvertible) lira continued to intensify, with the agio (discount on the official parity) peaking at 14 percent in the second half of 1893 (up from 4-5 percent in the first half of the year). At the end of 1893 Italy suffered a massive capital outflow which brought about the collapse of two major commercial banks, Banca Generale and Credito Mobiliare, and of several minor institutions. The government responded by keeping the planned resumption of convertibility on hold, expanding money supply by reducing the tax on excess circulation, and implementing a fiscal adjustment. ${ }^{95}$

\section{E. The Recovery After the Crisis}

During the decade following the crisis of Banca Romana, the industrialization of Italy finally took off on a large scale; growth accelerated to 2.6 percent a year (and industrial growth to 4.7 percent), and new large banks were established, mostly with German capital (Banca Commerciale, Credito Italiano), ${ }^{96}$ in line with the political alignment with Germany and Austria in the framework of the Triple Alliance established in 1882. In 1903 the lira became de facto convertible again, at the previous parity, although this change in regime was never formalized.

Politically, this was a period of transition, with an alternation of cabinets of different political orientation, ${ }^{97}$ that ended with the return to the scene of Giovanni Giolitti. Giolitti had been Treasury Minister and later Prime Minister during the crisis of Banca Romana (and had even had to flee the country at some point in the wake of the scandal) but, with his resignation and clever maneuvering (possibly including some illegal actions such as the subtraction and

\footnotetext{
92 Complementarity between the two was excluded. Free-market economists were concerned that government supervision would hamper market discipline by reducing market incentives to monitor the banks; since government supervision was also deemed to be less effective than private sector monitoring, its introduction was feared to weaken the stability of the financial system.

${ }^{93}$ Gigliobianco and Giordano (2010).

${ }^{94}$ See footnote 60 .

${ }^{95}$ See Bonelli and Cerrito (2003) and Negri (2003).

${ }^{96}$ Between 1893 and 1903 value-added in banking grew at an average real annual rate of 8.5 percent above the average of the $1874-87$ period.

97 Antonio Starabba, Marquess Di Rudinì (Right), 1896-98; General Luigi Girolamo Pelloux, 1898-1900; and Giuseppe Saracco (Left), 1900-01. The appointment of Zanardelli as Prime Minister in 1901 marks the start of a period of greater political stability generally known as the "Age of Giolitti." (see for instance Mack Smith, 2003).
} 
concealment of documents), managed to extricate himself from the worst of the scandal and was able to resurface in politics as Minister of the Interior in 1901 and again as Prime Minister in 1903; henceforth, he would dominate the political scene up to the outbreak of the first World War.

The Bank of Italy became a de facto monopolistic issuing bank and acquired an increasingly stronger public role (while losing the independence to pursue private sector profit objectives), gradually assuming all the functions of a central bank (eventually confirmed with the reform of 1936). ${ }^{98}$ Banco di Napoli and Banco di Sicilia lost the entitlement to issue notes in 1926 but survived, until recently, as commercial banks with a regional semi-public role. ${ }^{99}$

\section{Discussion}

The case of Banca Romana is an example of a crisis involving a systemic financial institution that stems from a combination of economic factors, institutional weaknesses, and political influence.

The economic drivers of the crisis can be easily traced to the construction and property boom of the 1880s, which was, in turn, the result of a credit boom spurred by an inflow of foreign capital. This pattern is not unusual in emerging economies (as Italy was at the time), where capital inflows frequently lead to an exchange rate appreciation and a credit boom that, in turn, increases the risks of a crisis. For instance, Kaminsky and Reinhart (1999) have found that banking and currency crises tend to occur in the wake of a prolonged economic boom fueled by credit and capital inflows (especially if banking regulation and supervision are weak) accompanied by an overvaluation of the currency; similarly, Reinhart and Reinhart (2008) have documented how episodes of intense but temporary large capital inflows ("bonanzas") are associated with a temporary deterioration of the current account balance, an appreciation of the real exchange rate (both of which occurred in Italy in the 1880s) and a boom in asset prices (such as that experienced in Italian real estate). When capital flows revert, the exchange rate depreciates and asset prices adjust, often triggering a crisis. ${ }^{100}$ Goodhart and Delargy (1998), comparing nine pre-1914 crises (including Italy in 1893) with the 1997 Asian crisis found a similar pattern: growing capital inflows financing an investment boom and current account deficits, leading to a spike in asset prices and a rapid

\footnotetext{
98 The first years of its existence were, indeed, characterized by the tension between its management, that cared mainly about the private interests of its shareholders, and Treasury Ministers that asked it to play increasingly more public functions (Bonelli and Cerrito, 2003; Negri, 2003).

${ }^{99}$ Both banks were turned into joint-stock companies in 1991. Banco di Napoli was temporarily merged with Sanpaolo IMI (now Intesa Sanpaolo) in 2002, of which it remains today a subsidiary (http://www.group.intesasanpaolo.com/scriptIsir0/si09/chi_siamo/eng banco_napoli.jsp, accessed on March 22,2017). Banco di Sicilia was acquired by Banca di Roma in 1999 and merged with the latter into UniCredit in 2010 (http://www.treccani.it/enciclopedia/banco-di-sicilia_(Dizionario-di-Economia-e-Finanza)/, accessed on March 22,2017).

${ }^{100}$ Kaminsky and Reinhart (1999) have found that equity price bubbles are a good predictor of banking crises.
} 
credit expansion, followed by a downturn in asset prices that strains the overextended banking system, often leading to a reversal of capital flows.

Government intervention also played a role. On one side, the need to finance recurrent deficits ${ }^{101}$ induced the government to grant special privileges to the issuing banks, starting with the BNR (which alone had the financial capacity to provide the large loans it needed) and extending them to the other issuing banks under the pressure of lobbying and vested regional interests. ${ }^{102}$ From 1885 , the government also prompted the issuing banks to expand credit supply in order to support economic activity and, later, rescue failing banks and enterprises that had come under strain during the downturn. This interference sent mixed signals on the government's preparedness to enforce its own regulations, paving the road to abuse.

Institutional weaknesses contributed to the crisis, although they should be traced less to a lack of surveillance powers than to a reluctance to use them effectively, amid prevailing views that the government should not intervene in the banking system, even as a regulator. The Minghetti Law in 1874 had introduced a systematic regulation of the issuing banks (previously governed only by the Commerce Code and by their own by-laws, with the exception of the BNR), establishing the principle that the government was entitled to exert "ample surveillance and supervision" (Art. 28). A subsequent regulation (Royal Decree of January 21, 1875, No. 2372) clarified that, as long as the currency remained nonconvertible, responsibility for surveillance was vested formally with the Ministry of Finance and effectively with the Ministry of Agriculture, except for major policy measures which had to be agreed between the two Ministries. The banks had to comply with government requests for information and documents and to submit the minutes of their shareholders' and directors' meetings. Government inspectors could make unannounced on-site visits. The bank had to publish their annual (or half-yearly) reports and to publish financial statements every ten days, and the Minister would report to Parliament once a year on the conditions of the banks. The law, however, did not specify sanctions for noncompliance, and the supervisory authorities were not politically independent (indeed, they were an integral part of the Executive); as a result, many of these provisions were largely disregarded, especially in the late 1880s. Banks frequently failed to submit their statements regularly, and between 1880 and 1889 no on-site inspection was carried out, ${ }^{103}$ at a moment when they would have been most useful. Some of these shortfalls were corrected, in part, after the crisis. The legislation introduced since 1893 provided much stricter provisions for surveillance; for instance, it clarified the bank administrators' responsibility for noncompliance, attributed responsibility for surveillance to a well specified unit at the Treasury under the supervision of

\footnotetext{
${ }^{101}$ Although the government budget was brought to balance in 1874, the Historic Left government coalition that came to power in 1876 brought it back into deficit territory by 1882, where it remained for the next fifteen years.

${ }^{102}$ An example is the corso forzoso - legal tender without convertibility - that was granted to the BNR in 1866 when the government borrowed 270 million lire from that bank to finance the war against Austria and extended (de facto) to the other issuing banks with the Minghetti reform of 1874 (see Gigliobianco and Giordano, 2010).

${ }^{103}$ Mordini at al. (1893), p. 6361.
} 
a permanent committee, and set clear minimum deadlines for on-site inspections. A series of regulations specified, in much greater detail than before, how these surveillance functions were to be carried out.

But a key contributing factor was the system of political collusion centered around the bank's governor, Bernardo Tanlongo. This system permitted and even encouraged the bank to engage in irregular and risky operations, bringing about its ultimate demise. While other issuing banks (such as BNR or Banco di Napoli) engaged in questionable and risky operations (which, due to their larger size, may have occurred even of a larger scale than Banca Romana), only Banca Romana collapsed, because only this bank engaged systematically, under cover of political protection, in irregularities, deception, and fraud, on a scale that wiped out all its capital.

This system of complicities developed, in turn, amid a combination of historical, cultural, geographic, personal, and more generally political factors that deserves some further scrutiny. In the decades following unification, the Italian political system was highly fragmented and the ruling coalition, in a changing world, was increasingly kept together more by patronage than by a shared political vision.

Some political cleavages were inherited from the unification process or emerged largely as a result of it. Predictably, there were differences of interests between the various regions (and, more specifically, between the elites that dominated the different regions); there were also differences concerning the form of government that the new nation should adopt, whether republican or monarchic, centralized or decentralized, based on a strong executive or on a stronger role for parliament. Relations between the state and the Catholic church was another major matter of contention, especially after the annexation of Rome ended abruptly the Pope's secular power.

There were also stark differences by class. While the nobility was gradually losing power and influence in favor of an emerging - but restricted - class of industrialists and financiers, large swathes of the population struggled in poverty and remained semi-illiterate. The increase in the number of industrial workers (even as agriculture remained the dominant sector) and the gradual extension of the suffrage resulted in a growing organization, representation, and voice of new movements representing them, most notably the "radicals," anarchists, and socialists composing the "extreme" Left and, later, the Catholic labor and cooperative movement.

Despite this political fragmentation, the country was ruled by a comparatively compact political coalition that gradually expanded and coopted new members. Cabinets were shortlived but their members were drawn from a small and cohesive group of people taking turns at various portfolios with short spells in the opposition. The cohesion of this coalition came, however, to be based increasingly more on patronage, the exchange of favors, and outright corruption than on a shared political program and ideological vision. The extension of the suffrage in 1882 produced a sharp increase in campaign costs, providing additional incentives to engage in patronage and corruption. In this environment, the presence of a bank 
willing to provide funds in exchange for political protection came as a boon to many politicians.

The business culture of Banca Romana had been, historically, less than stellar. Under the government of the Pope, in 1866, the bank had already been on the brink of bankruptcy. ${ }^{104}$ Things improved somewhat under Guerrini's direction after the annexation to the Kingdom of Italy, ${ }^{105}$ but turned again for the worse when the management was taken over by Bernardo Tanlongo, who was bent more on cultivating powerful connections than on managing the bank prudently and efficiently. These connections mobilized political support for the bank whenever the recurrent controversies over the reform of the credit sector would resurface or a banking reform law was tabled for discussion in Parliament.

The location of this bank in Rome was key. In that era, geographic proximity was essential for good communications, especially when their content was sensitive or on the fringe of the law. The establishment of an intricate system of collusion like that developed by Tanlongo also required intense personal contacts, with frequent meetings at social events and an exchange of messages and services through a complex system of intermediaries that only geographic proximity would permit. Nowhere else could top politicians, journalists, patricians, bureaucrats, and bankers meet as easily and frequently.

These connections also delayed the detection of the crisis and hampered government intervention. With so many parliamentarians and government officials involved, it was to be expected that the machinery of government would try as much as possible to cover up the scandal and delay its resolution. ${ }^{106}$ It is however remarkable that, when the Alvisi inquiry made at least a few top public officials, politicians, and cabinet ministers fully aware of the irregularity and weakness of the bank's position, they responded not only by trying to conceal the report from the public but continued to tolerate (and perhaps even take part in) the perpetration of these irregular deals, even at an accelerated pace. The situation of the bank worsened considerably in the period following the Alvisi inquiry, when a prompt intervention by the government might still have salvaged it, and the action of politicians, instead of rescuing it, brought forward its demise.

Could the crisis have been avoided? Several indications suggest that a systematic use by the government of its powers of supervision, and a more rigorous implementation of existing prudential regulations and governance rules (including the bank's own by-laws) could have prevented the worst excesses and, in the least, forced the administrators to exploit more

104 Atti Parlamentari, Camera dei Deputati, XVIII Legislatura, Ia. Sessione "2a.tornata di mercoledì 28 giugno 1893," resoconto stenografico, p. 5678 (speech by the Hon. Montagna).

105 Poddi (2016).

${ }^{106}$ A few months earlier (February-March 1888), inspectors with stakes in two major borrowers of the Banque de France (Société Industielle et Commerciale des Métaux and Comptoir d'Escompte) failed to report to its Council of Regents about the mounting imbalances of these companies, who would later require a major rescue intervention (Hautcoeur et al., 2014). Conflicts of interests and weaknesses in governance were thus not peculiar to Italy or Banca Romana. 
sophisticated schemes, thereby containing the extent of the fraud. For instance, the issue of unauthorized banknotes was easily detected at the first on-site inspection; other irregularities, including the excess circulation, shortage of cash, and falsification of accounts, were also hard to conceal from a diligent examiner. The failure to conduct such inspections should not, however, be interpreted only as a sign of collusion or deliberate intent to conceal these activities. As noted above, the public sector's responsibility to supervise the financial sector in order to ensure its stability was not universally acknowledged at the time; consensus leaned, if anything, in the opposite direction. Economists were concerned that public oversight would weaken private incentives to monitor the banks, and such incentives were seen as the most effective check on bank management. At the time, banks did not cater to a mass consumer market but to a restricted, closely knit, and well informed commercialpolitical elite, and it was far from clear who, between them and the government, had a comparative advantage in monitoring and enforcing prudential standards. With ex post wisdom, the private sector proved inadequate to the task. ${ }^{107}$

Things might have gone differently had the financial system been restructured sooner, for instance attributing the monopoly of issue, together with some other public functions, to a single central bank. The matter had lingered for years on the parliamentary agenda but vested interests, contrasting views, and a lack of proper theoretical underpinnings prevented the formation of the necessary consensus. It was, indeed, the crisis that precipitated the reform, as the issue of the resolution of Banca Romana got intertwined with the broader question of the reform. As frequently happens, the final solution reflected more a compromise along the path of least resistance than the most efficient and elegant theoretical vision. Banca Romana was liquidated, but responsibility for honoring its liabilities was transferred to the newly established Bank of Italy; the other issuing banks were merged, but the two non-profit southern banks, which enjoyed strong political support and played a semi-public regional development role in the country's poorest areas, preserved their independence and privileges, although their role became increasingly marginal. Convertibility was restored in principle but took ten years to implement in practice; in the meantime, the value of the currency was anchored to a quantitative monetary target through strict legal limits on circulation. ${ }^{108}$

Was Banca Romana of systemic importance? The answer is not clear-cut. On one side, the bank's role as the third largest issuing institution placed it at the core of the Italian financial system; its credit provision to commercial banks and enterprises entailed the risk that its bankruptcy could reverberate throughout the system, taking down, in its wake, a number of other institutions (what today would be called interconnection risk), although this risk was

107 This failure may reflect a significant element of moral hazard as private sector stakeholders may have expected to be bailed out by some sort of government intervention. As discussed below, this actually occurred for most creditors of Banca Romana, whose liabilities were taken over by the Bank of Italy, but not for Banca Romana's shareholders, who lost the entire value of their shares (despite an early proposal to grant them a partial refund). The latter, and the members of the Board of Directors, could have intervened against Tanlongo's centralized and secretive management by enforcing the Bank's constitution and by-laws, but failed to exert this power. 
stronger in the case of the BNR (and perhaps Banco di Napoli) than of Banca Romana. ${ }^{109}$ The bank was also an important component of the payments system; although its note circulation was mostly limited to the region around Rome, a loss of confidence in its currency could potentially spread to other issuing banks, starting with Banco di Napoli (which was also affected by various management issues), whose circulation was much larger and extended to all the southern regions, and possibly reaching even the BNR, to which the market may have attributed an implicit guarantee on the notes of the other issuing banks. On the other hand, by size and assets, the bank was not particularly significant. At its peak in 1892, despite the unauthorized and fraudulent excess, its note circulation amounted to less than 8 percent of the total and to about 1 percent of GDP; its assets amounted to a mere 7 percent of the assets of all the issuing banks. Its geographical location in Rome also implied that its crisis could have had a limited impact on the country's economic expansion, which was centered in its north-western provinces. True, the bank may have had a systemic impact at the regional level, which may have been particularly critical in view of the country's recent history (Rome had been annexed just two decades before and the controversy surrounding the relations between the Church and the State was still tense), strong geographic sensitivities (that continue, more weakly, to this day), and of the fact that this region included the capital. Nevertheless, the suspicion remains that the alleged systemic importance of the bank may have been exaggerated by many politicians and influential opinion makers with a stake in it.

Who paid, eventually, for the resolution of the bank? Answering this question requires, in the first place, to estimate the actual extent of the losses incurred by the bank, which, in the absence of detailed information, are subject to a wide margin of uncertainty. The losses did not appear all at once, since most of the bank's assets were "immobilized" in long-term investments that could be unwound only gradually. Taking Finali's assessment that 16 million lire of its assets were nonperforming and that another 18.2 million were long-term assets hard to liquidate without major losses, assuming a recovery rate of 25 percent for both, additional losses of 10 percent on its total portfolio and active current accounts (equivalent to 11.4 million), and adding the 28.6 million cash shortfall uncovered by the investigation, the bank's total losses can be estimated at about 65 million. ${ }^{110}$ In a more optimistic scenario entailing a recovery rate of 50 percent and losses of only 5 percent on the loan portfolio and current accounts, total losses would decline to about 50 million; with less favorable assumptions (recovery rate of 10 percent, loss rate of 20 percent) total losses would instead rise above 80 million (Table 4). By comparison, the Law of 1893 implicitly assumed an

\footnotetext{
${ }^{109}$ Other issuing banks (most notably the BNR) were exposed to Banca Romana through the balances of banknotes held in their vaults and not converted, owing to the suspension of the riscontrata (settlement of reciprocal cash holdings). Commercial banks were exposed through their balances of Banca Romana banknotes and through the balances of their current account deposits at Banca Romana.

${ }^{110}$ This would be equivalent to a 35 percent loss on the bank's private sector credit, which at end-1892 amounted to 104 million lire (68 million of loans, of which 1.6 million anticipations, 30 million active current accounts, and 4 million mortgages: de Mattia, 1967). It can be presumed that the value of the bank's other assets (46 million, of which 4 million claims on the government, 27 million cash, 7 million buildings, and 9 million various other claims: ibid.) could have been fully recovered, at least over the 18-year period taken for the bank's liquidation.
} 
expected value of 40 million, and the subsequent Convention of October 30, 1894 a value of about 100 million. ${ }^{111}$

\section{Table 4. Estimates of the Total Losses Incurred by Banca Romana (million lire, unless otherwise indicated)}

\begin{tabular}{llll}
\hline & $\begin{array}{l}\text { Low } \\
\text { estimate }\end{array}$ & $\begin{array}{l}\text { Middle } \\
\text { estimate }\end{array}$ & $\begin{array}{l}\text { High } \\
\text { estimate }\end{array}$ \\
\hline NPL ${ }^{112}$ and immobilization recovery rate (percent) & $50 \%$ & $25 \%$ & $10 \%$ \\
Loss rate on portfolio and active current account (percent) & $5 \%$ & $10 \%$ & $20 \%$ \\
Losses on NPLs and immobilizations & 17.1 & 25.6 & 30.6 \\
Losses on portfolio and active current accounts & 5.7 & 11.4 & 22.8 \\
Cash shortfall & 28.6 & 28.6 & 28.6 \\
Total losses & 51.6 & 65.6 & 82.0 \\
\hline
\end{tabular}

Source: Estimates based on data reported in the Finali Report. ${ }^{113}$

The bank's shareholders lost, of course, their capital ${ }^{114}$ of 15 million lire; ${ }^{115}$ as noted above, if they had been more diligent in calling the bank's management into account, the crisis, and their loss, could have been averted. The bank's creditors (including the holders of Banca Romana's banknotes) ${ }^{116}$ were instead bailed out, as the Bank of Italy became responsible for

\footnotetext{
${ }^{111}$ Equivalent to the 40 million lire provided in Art. 29 of the Law of 1893 plus the sum of the additional provisions established in Art. 2 of the Convention to cover any additional losses and liquidation costs (57 million). This should not be confused with the sum of about 100 million posted on the balance sheet of the Bank of Italy as "current account" for Banca Romana, corresponding to the assets to be liquidated.

112 Nonperforming loans.

${ }^{113}$ As reported by di Nardi (1953).

${ }^{114}$ According to Corriere della Sera (January 19 and February 26, 1893), the initial convention between the BNR, the two Tuscan Banks, and Banca Romana provided that Banca Romana's shareholders would be reimbursed 45 percent of the nominal value of their shares, which was equivalent to the price at which they traded at the end of January (see also Civiltà Cattolica, 1893, and Negri, 2003). This provision was not included either in the Law of 1893 or in the subsequent Convention, replaced by an agreement that BNR shareholders would sell shares of the new Bank of Italy to Banca Romana's shareholders at their nominal price of 700 lire, net of any market premium (Corriere della Sera, June 6 and November 1, 1893). Banca Romana's shareholders challenged this omission all the way to the Supreme Court (Corte di Cassazione), which may explain why (according to the data reported in the Gazzetta Ufficiale del Regno d'Italia) the shares of Banca Romana continued to trade at about 40 percent of their nominal value for most of 1893 and subsequently at 30-35 percent, to recover to 43.5 percent by March 12, 1896, the last day they were quoted in the Rome Stock Exchange.

${ }^{115}$ Not counting any premium they may have paid for the shares, whose nominal value was 1,000 lire each.

${ }^{116}$ In a regime of legal tender, the holders of banknotes could claim at least an implicit guarantee on the government. On the basis of this consideration, Art. 26 of the Law of 1893 mandated the Bank of Italy to convert Banca Romana's banknotes, on demand, with notes of the BNR.
} 
all the liabilities of Banca Romana. ${ }^{117}$ The notes of Banca Romana continued to circulate for three more years, until they were withdrawn from circulation in 1896 and replaced with the notes of the Bank of Italy.

With the Law of 1893 and with the Convention of October 30, 1894, ${ }^{118}$ the responsibility for liquidating Banca Romana was assumed by the Bank of Italy, which would absorb the rest of the losses and was required to set aside for this purpose an annual provision of 2 million lire for twenty years (for a total of 40 million), ${ }^{119}$ later raised, for ten years, to 8 million, ${ }^{120}$ bringing the cumulative total to 97 million. The bank was, however, compensated by the government with a rebate on the circulation tax and with the monopoly of issue and legal tender for its notes. The tax rebate was of course borne by the taxpayer; the Law of 1893 granted a reduction of 0.44 percent on 60 percent of the circulation, which would have entailed a cumulative revenue loss for the government of about 24 million from 1894 to 1906, rising to more than 35 million by 1912. Taking account of the additional rebate granted with the Convention of November 28, 1896, and comparing the tax actually paid with the amount theoretically due if the rate had been left unchanged at 1.44 percent, the total revenue loss borne by the government until 1906 alone could have been almost twice that amount, at about 40-45 million; ${ }^{121}$ extrapolating to 1912 , the total fiscal loss may have been of the order of about 60 million, or about 0.5 percent of 1893 GDP. As already noted, not all of this loss was associated with the liquidation of Banca Romana, as the tax rebates also aimed at encouraging a speedy liquidation of the other long-term assets held by the bank, and were accompanied by a provision granting the government a large share of the bank's profits if they exceeded 5 percent of capital.

\footnotetext{
${ }^{117}$ Banca Romana's liabilities at end-1892 amounted to 131 million lire, of which 112 million were currency in circulation, 1.4 million were owed to the government, 15 million were deposits, and 3.3 million were other liabilities, including some arrear dividends (de Mattia, 1967).

${ }^{118}$ Convention of October 30, 1894, between the Treasury Minister and the Bank of Italy, approved by Royal Decree of December 10, 1894, No. 533, converted into law with the Law of August 10, 1895 No. 486.

${ }^{119}$ Art. 29 of the Law of August 10, 1893 No. 449 established that any losses in excess of this amount would be borne by the state, whereas if total losses were less than this amount the difference would be capitalized by the Bank of Italy. With the Convention of October 30, 1994 the risks of the liquidation of Banca Romana were assumed in their entirety by the Bank of Italy.

${ }^{120} 6$ million lire in 1894, 7 million in 1895, and 8 million every year from 1896 to 1903 (Convention of October 30, 1894, Art. 2).

121 The total revenue loss borne by the government was actually higher as part of the tax rebate spilled over to Banco di Napoli and Banco di Sicilia, whose circulation amounted to about one-fourth of the total and who also benefited from the tax rebate, without incurring any of the costs of the liquidation. This additional loss should however be considered a transfer to those institutions and cannot be counted among the costs of liquidating Banca Romana. It might be argued, perhaps, that these transfers were granted only as a side effect of the government's need to compensate the Bank of Italy for the liquidation of Banca Romana and were, in this sense, an indirect cost of that liquidation.
} 
Most of the rest was paid, directly and indirectly, by the Bank of Italy's shareholders. The Bank's capital was reduced two times, by a total of 60 million lire, in $1894^{122}$ and 1896 , to cover losses from the liquidation of its long-term, assets (originating primarily from the rescue operations performed between 1887 and 1894, and only in part from the liquidation of Banca Romana); in 1895, the capital reduction was offset by calling in an additional 100 lire per share, ${ }^{123}$ for a total of 30 million, which posed a direct financial burden on the shareholders. ${ }^{124}$ Moreover, for about a decade, profits and dividends remained depressed. Despite the tax rebate (part of which was introduced gradually and came into force only in later years), between 1894 and 1906 the Bank of Italy earned much lower profits per year than the three banks that merged into it had earned in the previous two decades (Table 5); as a result, it distributed much lower dividends. If one takes the average of the period 1888-93 (or 1906-12) as a benchmark, ${ }^{125}$ forgone profits over the 1894-1906 period amounted to about 6.6-6.8 million lire per year, for a total of about 80-82 million, resulting in about 76-82 million of forgone dividends, on top of the capital reductions. This shortfall stems from the need, established by law and convention, to set aside provisions for the losses that could arise from the liquidation of Banca Romana; part of these "losses" may have been later recovered if (as may have happened) the costs of the liquidation turned out to be lower than the cumulative provisions set against them. ${ }^{126}$ Between 1894 and 1906 these provisions amounted, in total, to 83 million; without them, the profits and dividends of the Bank of Italy would have amounted to about 13 million per year, broadly in line with the average for the period 1871-1912. ${ }^{127}$

${ }^{122}$ Art. 7 of the Convention of October 30, 1894.

${ }^{123}$ Art. 6 of the Convention of October 30, 1894.

${ }^{124}$ Only 70 percent of the nominal capital of 300 million lire had been paid in. The Convention of October 30 , 1894 provided for a capital devaluation of 30 million to be offset by calling in an additional 30 million of capital; nominal capital was thus reduced to 270 million, of which 210 million paid in. With the subsequent Convention of November 28, 1896, nominal capital was devalued again by 30 million to 240 million, of which 180 million paid in, but no additional payments were required of shareholders.

${ }^{125}$ Average dividends in these two periods were close to the average of the entire period 1871-1912, which can be considered as a long-term benchmark as it included both favorable and unfavorable moments. The period 1888-93 came after the unsustainable boom of the mid-1880s discussed in the text; the period 1907-12 falls during the country's industrial take-off and should have been particularly favorable to the Bank, which may have suffered from the burden of the liquidation even during this period. If this is the case, taking this period as a benchmark results in an underestimate of the bank's foregone dividends.

${ }^{126}$ By end-1912, when the liquidation was completed, the cumulative provisions amounted to 97 million lire; as noted above, the costs of liquidation may have ranged from 60 to 100 million, including the cash shortfall.

${ }^{127}$ It may be argued that, since the shareholders of the Bank of Italy approved the conventions concerning the mergers of the bank and liquidation of Banca Romana, they must have been satisfied with the provisions and hence cannot have incurred a loss compared with the counterfactual "no-agreement" scenario that seemed most likely at the time. This presupposes, however, that they must have been fully informed by the Management of the banks, which conducted the negotiations and whose interests and objectives may have differed significantly from those of most shareholders. Moreover, many provisions were subsequently changed, either unilaterally by 
In summary, an amount of about 150 million lire (1.3 percent of 1893 GDP) was lost by the Bank of Italy between 1894 and 1912, of which 35 percent ( 60 million) was covered by the government in the form of tax rebates, and the rest was borne by the Bank of Italy's shareholders in the form of an additional capital injection (30 million) and foregone dividends ( 80 million). These losses included both the negative balances from the liquidation of Banca Romana and the losses incurred from the liquidation of long-term assets inherited by the Bank of Italy on its birth. Estimating the losses of Banca Romana at 80 million (a bit less than one half of the total, and in line with the upper bound estimated in Table 4), given that 15 million were absorbed by the bank's shareholders, we can assume that the remaining 65 million have been covered by the government in the above-mentioned proportion of 35 percent (about 23 million) and that the rest (42 million) have been borne by the shareholders of the Bank of Italy (Table 6). In the same way, if the losses of Banca Romana amounted to 60 (40) million, the government might have borne 16 (9) million. Altogether, it seems likely that the government may have borne at least one-fifth, and probably more than one-fourth, of the total losses of Banca Romana, for up to 0.7 percent of 1893 GDP - not a negligible amount, considering that it stemmed from the collapse of only one entity. ${ }^{128}$ This, however, occurred indirectly and in a non-transparent way, to the point that even today this magnitude is difficult to quantify.

Table 5. Bank of Italy: ${ }^{129}$ Net Profits and Dividends, 1871-1912 (annual average for each period; million lire, unless otherwise indicated)

\begin{tabular}{llll}
\hline & Net profit & Dividend & $\begin{array}{l}\text { Dividend per share } \\
\text { (lire) }\end{array}$ \\
\hline $1871-80$ & 20.4 & 19.2 & 115 \\
$1881-87$ & 19.6 & 17.9 & 89 \\
$1888-93$ & 12.5 & 11.7 & 58 \\
$1894-1906$ & 5.9 & 5.4 & 18 \\
$1907-12$ & 12.7 & 12.2 & 39 \\
$\mathbf{1 8 7 1 - 1 9 1 2}$ & $\mathbf{1 3 . 5}$ & $\mathbf{1 2 . 6}$ & $\mathbf{6 2}$ \\
\hline
\end{tabular}

Source: de Mattia (1978).

the government or in agreement with the government, at a time when the Bank of Italy's bargaining position must have been much weaker (see for instance Bonelli and Cerrito, 2003, and Negri, 2003).

${ }^{128}$ Using the same method, the government share of the losses would have been less than 25 percent only if the total amount of the losses had been less than 52.5 million lire.

${ }^{129}$ Data for the period 1871-93 refer to the three issuing banks that merged into the Bank of Italy. 
Table 6. Estimated Sharing of the Losses of Banca Romana (million lire, unless otherwise indicated)

\begin{tabular}{lcccccc}
\hline & \multicolumn{2}{c}{ Loss scenario } \\
Entity & \multicolumn{2}{c}{ High } & \multicolumn{2}{c}{ Middle } & \multicolumn{2}{c}{ Low } \\
\hline Banca Romana's Shareholders & 15 & $18 \%$ & 15 & $25 \%$ & 15 & $38 \%$ \\
Bank of Italy's Shareholders & 42 & $53 \%$ & 29 & $48 \%$ & 16 & $40 \%$ \\
Government & 23 & $29 \%$ & 16 & $27 \%$ & 9 & $22 \%$ \\
Total losses & 80 & $100 \%$ & 60 & $100 \%$ & 40 & $100 \%$ \\
\hline
\end{tabular}

Sources: estimates based on data from de Mattia (1978) and other sources.

The general public felt the economic impact of a transition to an effective monopoly of issue, which may have provided some benefits to the Bank of Italy in terms of seigniorage, but may have also benefited, indirectly, the public at large, by enabling a more efficient financial system and the emergence of an institution capable of playing the role of a modern central bank; the value of these benefits is of course difficult to quantify. ${ }^{130}$ The reform also happened at a favorable time: in the twenty years since 1894, real GDP, which until then had been rising at a moderate pace, grew at an average rate of 2.2 percent (it accelerated even further after 1898), absorbing a nominal increase in circulation of 1.6 percent per year. ${ }^{131}$ Between 1894 and 1912 (when Banca Romana's liquidation was completed) the circulation of the Bank of Italy increased by about 870 million lire. Although not all this amount was pure seigniorage and although under the new legal provisions the Bank could not really benefit from seigniorage, the national economic expansion brought about improvements in other areas of business which increased the profits of the Bank of Italy. ${ }^{132}$ As a result, the Bank of Italy was still able to return a profit and distribute a regular dividend throughout the period, which returned to more "normal" levels after 1906. ${ }^{133}$ In some way, the politicians involved in the scandal may have been fortunate that the actual costs of the resolution of

${ }^{130}$ While the Bank of Italy was initially run as a private institution, it gradually assumed an increasingly larger public role until it was de facto nationalized in 1936.

${ }^{131}$ The circulation grew less than GDP because the multiplier increased over the same period, from 2.3 in 1894 to 3.7 in 1913. Over the same period, broad money grew more rapidly than real GDP, at an average annual rate of 4 percent, as money velocity declined; inflation, initially negative, turned positive after the turn of the century, reaching an average annual rate of 0.5 percent over the period.

${ }^{132}$ Gigliobianco and Giordano (2010) claim that "Banca Romana's losses were swept under the carpet, as they were covered by Bank of Italy's seigneurage" (p. 18). It is unclear, however, how the Bank of Italy could have benefited from it. Its circulation was capped by law at 800 million lire, and mandated to decline to 630 million over 14 years; this limit could be exceeded only by holding an equivalent amount in non-interest bearing metal reserves, or in credit to the government. Most of the increase in circulation between 1894 and 1912 actually went to increase the metal reserve, and so would not have improved the bank's profitability. Instead, the significant increase in the bank's profits (from 4.8 in 1894 to 6.6 million in 1906) stemmed from a sharp increase in interest earnings from short-term loans (Confalonieri, 1974), and therefore was not directly related to the expansion of the circulation.

${ }^{133}$ The high profits observed before 1887 were unsustainable and cannot be considered "normal," as they stemmed in part from investments in long-term illiquid assets; the associated "demobilization" costs contributed to depressing the earnings between 1894 and 1906. 
Banca Romana were largely concealed by the gains in efficiency obtained through the reform, amplified by the favorable economic moment. If growth in Italy had remained as lackluster as in the previous two decades, it is conceivable that the debate over the distribution of these costs might have re-emerged more frequently and vigorously.

The crisis also brought about other, indirect, costs. In 1894, in the climate of uncertainty following the reform (and amid the turbulence in the wake of Barings' collapse), two major commercial banks - Banca Generale and Credito Mobiliare - together with a number of minor banks, went bankrupt, and economic conditions remained generally weak. ${ }^{134}$ Nevertheless, it can be argued that in the long term the new issuing arrangements facilitated if they did not even contribute to launching - the industrial take-off that took place, eventually, around the turn of the century.

Due to the large involvement of top public officials, the crisis had important political repercussions. The crisis marks a turning point in the decade-long domination of the Italian political scene by Francesco Crispi, a period characterized by colonial expansion, the commercial war with France, a tough attitude on law-and-order, and hostility to the rising socialist movement. Crispi's resignation in early 1896 was followed by a period of social unrest amid attempts to enforce a more centralized and authoritarian style of government, but after the turn of the century (and under a new King) Italian politics converged again to a more liberal stance under the leadership of Giovanni Giolitti - which endured until the World War broke out in 1914. The so-called "Age of Giolitti" brought about a further extension of the suffrage, accompanied by the gradual political integration of the labor movement in its different forms (socialism, Catholic cooperation, trade unionism) and rapid improvements in economic and social conditions.

How much of these changes were influenced by the crisis? By bringing to an end a system of illegal financing of political campaigns and collusion, the crisis might have weakened an important part of the old political establishment and facilitated the emergence of new forces and people. The evidence of this is, however, scant at best. Most of the deputies who served in the XVIII legislature elected in 1892 were re-elected to the XIX and XX legislatures in 1895 and $1897 .{ }^{135}$ Moreover, ongoing social and economic trends, such as the expansion of industry and, with it, an organized labor force, and even incidental events such as the assassination of the King in 1900, played, arguably, a much larger role in bringing about political change in this period.

The most visible political effect of the crisis was the temporary retreat from the limelight of Giolitti, whose promising political career was set back for about seven years. Crispi led another cabinet after the crisis and his exit from the political scene was caused more by

\footnotetext{
${ }^{134}$ Amid widespread unemployment and poverty, insurrections broke out in Sicily (Fasci) and Tuscany, that were heavily repressed by the government.

${ }^{135}$ Duggan (2002) notes that, although the 1895 elections returned a majority of 334 seats out of 508 in support of Crispi, their share of the popular vote amounted to a less impressive 58 percent, reflecting the adverse impact of the banking scandal. According to Saladino (1974) the opposition, during the campaign, "made much of the 'moral question' involved in Crispi's relations with Banca Romana" (p. 40).
} 
military disasters in Africa than by the repercussions of the banking crisis, although the attacks led on him by Giolitti may have weakened his support in the Chamber, and it is also possible to speculate that his political influence could have lasted longer had the demise of Banca Romana not disrupted a major source of financing. Corruption could not be expected to end with Banca Romana, and it did not. It continued, perhaps on a larger scale, under Giolitti - who was later dubbed by an opponent ministro della malavita, Minister of Crime. It took, however, different forms that did not directly involve the issuing banks.

It is worthwhile to recall here the assessment given, about half a century after the event, by the Italian philosopher Benedetto Croce. "Swindlers, businessmen without scruples or dignity, fraudulent administrators, disloyal or greedy officials, and small and large robberies - he noted - occur at all times and in all countries... but the true evil occurs when... they do not provoke the reaction of an honest conscience, and correction and punishment; which cannot be said to have been the case in Italy. Here... the "scandals" ceased to be such, precisely because they were qualified and treated as such." (Croce, 1947, pp. 200-1). ${ }^{136}$

\section{Conclusions}

A century and a quarter after the crisis of Banca Romana, the importance of maintaining a stable and healthy financial system has increased enormously as a result of the much higher sophistication and interconnection of modern finance. So is the experience of Banca Romana still relevant today? Arguably, a close look at this case can still provide insights and guidance that can strengthen the current capacity to exert an effective supervision of the financial system and prevent - and, in case, promptly and smoothly resolve - a crisis.

The crisis of the bank occurred within a wider economic crisis, in the wake of a period of prolonged and rapid credit expansion, low inflation, and positive, though modest, real growth, associated with ample liquidity induced by a reversible capital inflow (Figure 21). As discussed in Section IV, such a configuration frequently results in an unsustainable increase in asset prices and in an accumulation of imbalances that eventually strain the banking system. When similar conditions occur in a country, the risk that apparently stable conditions could conceal an increase in vulnerabilities should therefore receive heightened attention. When strains started to appear after 1887, the Italian government's response was not directed at correcting these imbalances but focused instead on prolonging artificially the past trends by injecting more liquidity in the system. This type of response is not uncommon, but exacerbates the imbalances and opens the door to abuse, postponing, but not preventing, the eventual correction, as happened in the case of Banca Romana. In such situations, experts' alerts about the emerging risks and calls for a prompt intervention often meet with a muted response. A deeper understanding of the underlying political economy may explain when, under what conditions, the authorities may be more inclined to take action. In the case of Banca Romana (which, even in this aspect, is not uncommon), a major obstacle arose from the fact that the people who had the authority to intervene were also reaping benefits from the status quo, which may have blinded them to its unsustainability.

136 This paper's translation from the original Italian text. 
Figure 21. Italy: Real GDP Growth, Inflation, and Credit Expansion, 1874-89 (percent)

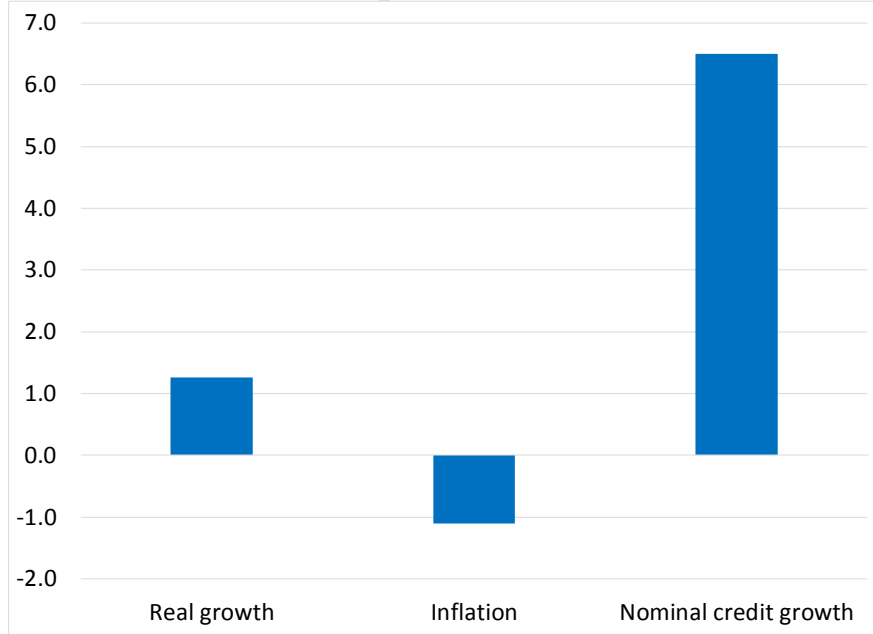

Sources: ISTAT/Bank of Italy.

The crisis revealed deep-seated weaknesses in the financial and political system. The delay of the reform of the financial system, with an asymmetric six-bank oligopoly in banknote circulation and an unresolved confusion between their private and public role, created incentives for abuse that were exacerbated by weaknesses in governance. In addition, rising campaign costs and the lack of a cohesive government majority based on a shared political project encouraged an exchange of financial support for political cover.

A few other elements are notable in this picture. The lack of proper investment banks contributed to the crisis by inducing other institutions - issuing banks and large commercial banks - to fill this vacuum by taking on increasingly larger long-term and risky positions. In the absence of a clear-cut demarcation of their public and systemic role, the issuing banks competed with commercial banks in this line of business, partly financing their exposure with an increase in circulation. This operation was permitted by the government's forbearance, and even encouragement, in an effort to support the economy via credit expansion. At the same time, however, the government took other measures that aggravated the situation, at least in the short term: the commercial war with France resulted in the loss of a major export market, and the restoration of convertibility brought about a loss of competitiveness that further delayed the industrial development of the country. In the absence of growthenhancing productive investment opportunities, the credit expansion ended up inflating an asset price bubble.

While this accumulation of imbalances is conspicuous to a historical observer, it may have been difficult to detect at the time, especially in the absence of detailed and timely statistics. Political collusion and the involvement of the press in the circle of corruption not only set up a wall of disguise around the bank's abuses and irregularities, but mobilized public opinion especially the informed and influential public that was interested in these matters - in favor of the bank; an expert who did not have legal rights of access to the documents (that were 
hard to reach even for the examiners who visited the bank ${ }^{137}$ ) might have failed to detect the mounting strains and in any case would have probably underestimated their extent.

It is also notable that the imbalances continued to accumulate - indeed, accelerated - even after the crisis was detected at the official level. After the initial investigation, political corruption by the bank, financed with an illegal note circulation, was stepped up, probably in an effort to secure political cover and consolidate and expand support. It is now clear that at least some top cabinet ministers (including the Prime Minister himself) were aware of what was going on and of the seriousness of the situation. Why did they not intervene accordingly, knowing that the moment of reckoning would come at some point? In December 1893, when Banca Romana was already insolvent, Giolitti even presented to Parliament legislation aimed at prolonging the status quo for the next six years - a move that backfired, prompting opposition deputies to leak the results of the investigation, thereby precipitating the crisis. The propensity to delay difficult decisions is not uncommon, and politicians can always hope that it will be some future minister (or cabinet) that will take the blame when the crisis erupts; but reluctance to act may also have been favored by the general perception that the bank was covered by an implicit government guarantee. Since the corso forzoso, which made the bank notes not convertible, had been imposed by law, there was a shared perception that, if an issuing bank went into trouble, the government had a political and moral obligation to bail out its creditors; whence the continued willingness of the public to accept its notes, despite mounting rumors of financial strains, and whence the misleading perception that, since the implicit guarantee discouraged a run on the bank, the situation could continue indefinitely without reaching a point of rupture. Action, of course, was needed at some point; but was not perceived to be urgent, and the six-year extension of the existing arrangement had also the (ostensible) purpose of "buying time" to adopt and phase in appropriate measures to improve the situation of the issuing banks. In fact, such perceptions also encouraged the postponement of difficult decisions. With every day that passed, the problem was getting worse, raising the costs of the resolution and strengthening the reluctance to act.

The crisis, however, had the beneficial effect of forcing a rationalization of the banking sector that otherwise might have been further delayed. It convinced the public of the importance of a well-managed and well-supervised banking system, and the urgency of a resolution (especially upon realizing the politicians' vested interest in a solution that did not end with the liquidation of the bank) facilitated the achievement of the required support for an outcome along the path of least resistance. While the scheme adopted was not the most theoretically efficient, it brought about more clarity about the issuing banks' role and public responsibilities and provided an anchor to the value of the currency that, later, eased the return to convertibility.

\footnotetext{
${ }^{137}$ Some of the tactics used by Tanlongo during the Alvisi investigations included delaying the provision of documents, providing only partial or summary information when detailed accounts were requested, and providing statements referring to different dates that were, thus, hard to reconcile. These, and other, irregularities were at one point explained by claiming that the bank was run in a "patriarchal" way - caring for the substance with little regard to formalities (Atti Parlamentari, 1892, p. 716). In fact, the disregard for formality aimed at concealing the substance.
} 
The capacity to resolve the situation rapidly stemmed from the fact that the reform of the banking system had been discussed for years on the parliamentary agenda, albeit without approval. When action was required at short notice, plans and possible solutions had already been developed and explored at length and a political consensus could be rapidly formed around difficult decisions. In more normal circumstances, prompt action may be facilitated by the adoption - in less turbulent times - of comprehensive crisis resolution and contingency plans. Such plans can also make any post-crisis decision less controversial, as it will be based on standards that have already been discussed and accepted.

While it is not fully clear how the costs of the resolution were shared, it is evident that a large share of these costs was paid by the government (hence, by taxpayers) in an indirect and nontransparent way, mainly in the form of rebates on the circulation tax. Shareholders lost their capital investment, but this covered only a minor fraction of total costs because the bank was poorly capitalized. The rest of the costs were borne by the shareholders of the three banks that merged into the new Bank of Italy, in the form of capital devaluations and depressed dividends. The end result was an indirect transfer of real resources from taxpayers and from the shareholders of Banca Romana and of the banks that merged into the Bank of Italy to the people and companies who had received the cheap and unsecured loans from the Bank and who failed to fully repay their debts. ${ }^{138}$

Ultimately, the rapid economic expansion that took off around the turn of the century helped to conceal, and offset the pain of these costs. When the liquidation of Banca Romana was completed in 1912, the country's per capita GDP had increased by almost 60 percent in nominal terms, and 25 percent in real terms, compared with 1893. In an expanding economy that reached 23 billion lire per year, the 100 million (at most) lost with Banca Romana might have appeared manageable. Moreover, the economic recovery, by strengthening asset prices, might have also contained the losses from the liquidation. If economic developments had been less favorable, there might have been a much more contentious debate on who should bear the burden of the crisis.

\footnotetext{
${ }^{138}$ Other beneficiaries included the counterparties of transactions financed by these loans, such as owners that sold their property at high prices to people who had borrowed from the Bank.
} 


\section{ApPendiX A. Main Legislation Governing CuRRenCy IsSUe AND The IsSuing BAnKs, 1861-95}

- Law July 17, 1861 No. 123: established the Italian lira, with legal tender throughout the Kingdom.

- Law August 24, 1862 No. 788 (legge Pepoli): unifies the currency; sets common standards for coins.

- Royal Decree May 1, 1866 No. 2873 (GU May $2^{1}$ ): suspends convertibility and establishes legal tender; empowers the Government to supervise the issuing banks and to block the execution of operations contrary to the law or to the national interest.

- Royal Decree May 27, 1866 No. 2966: establishes a bank surveillance unit at the Ministry of Finance.

- Royal Decree September 5, 1869 No. 5256: attributes the surveillance responsibility over the issuing banks to the ministry of Agriculture, Industry, and Trade

- Royal Decree December 2, 1870 No. 6064: approves the new constitution of Banca Romana.

- Law April 30, 1874 No. 1920 (legge Minghetti; GU May 22): limits the authority to issue banknotes to the six existing Issuing Banks; sets legal limits to the circulation; establishes the Bank Consortium.

- Royal Decree September 23, 1874 No. 2237: sets the circulation limits;

- Royal Decree January 21, 1875 No. 2372: contains rules for implementing the Law April 30, 1874 No. 1920.

- Law April 7, 1881 No. 133 (GU April 8): reestablishes convertibility.

- Royal Decree August 12, 1883 No. 1592: authorizes excess circulation fully backed by metal reserves (up to 40 percent of capital).

- Royal Decree November 30, 1884 No. 2857: removes the cap of 40 percent of capital set in RD 1592.

- Law June 28, 1885 No. 3167 (GU same day): extends the legal tender to end-June 1886; limits the discount of bills to one-half of the authorized circulation; authorizes circulation in excess of the limits if it is fully backed by metal reserves under government supervision.

- Law June 30, 1891 No. 313 (GU same day): raises the circulation tax from 1 to 1.44 percent.

- Law June 30, 1891 No. 314 (GU same day): extends the legal tender to end 1892; requires each issuing bank to accept the notes of all the others; sets the circulation ceiling at the 1890 average or four times capital whichever is larger; and required reserve at one-third of the circulation; establishes a penalty for exceeding these limits.

- Law August 10, 1893 No. 449 (GU same day): establishes the merger of three issuing banks into the Bank of Italy (Banca Romana is liquidated).

- Royal Decree November 23, 1893 No. 644 (GU Dec. 9): approval of the regulation for the liquidation of Banca Romana 
- Royal Decree January 23, 1894 No. 9: reduction of the tax established by Art. 10 and 12 of the Law August 10, 1893 No. 449.

- RD October 12, 1894 No. 442: confers to the Treasury Minister sole responsibility for surveillance on the issuing banks.

- RD December 10, 1894 No. 533 (GU same day): ratifies the Convention of October 30, 1894, between the Government and the Bank of Italy, whereby the Bank of Italy assumes all the risks from the liquidation of Banca Romana.

- Law, August 8, 1895, No. 486: converts into law the RD December 10, 1894 No. 533, the RD October 12, 1894 No. 442, and several other provisions concerning the circulation and the issuing banks.

- RD December 6,1896 No. 517: ratifies the Convention of November 28, 1896.

- Law January 17, 1897 No. 9: converts into Law the Convention of November 28, 1896 and contains other provisions for Banco di Napoli.

- Law March 3, 1898 No. 47: exempts from the circulation tax an additional amount corresponding to the assets of Banca Romana under liquidation; amends some provisions of previous legislation. 


\section{APPENDiX B. Legislation EXTENDING THE LEgAL TENDER OF BANKNOTES, 1874-93}

- Law May 21, 1876, No. 3121 (for the consortium bills)

- Law December 26, 1877 No. 4212 (to June 30, 1878)

- Law June 30, 1878 No. 4430 (to June 30, 1879)

- Law June 29, 1879 No. 4953 (to January 31, 1880)

- Law January 29, 1879 No. 5245 (to June 30, 1880)

- Law June 30, 1880 No. 5515 (to December 31, 1880)

- Law December 31, 1880 No. 5809 (to June 30, 1881)

- Law December 25, 1883 No. 1772 (to December 31, 1884)

- Law December 31, 1884 No. 2849 (to June 30, 1885)

- Law June 28, 1885 No. 3167 (to June 30, 1886)

- Law June 30, 1886 No. 3944 (to June 30, 1887)

- Law June 30, 1887 No. 4625 (to June 30, 1888)

- Law June 30, 1888 No. 5486 (to June 30, 1889)

- Law June 30, 1889 No. 6143 (to December 31, 1889)

- Law December 25, 1889 No. 6570 (to June 30, 1891)

- Law June 30, 1891 No. 314 (to December 31, 1892)

- Law December 25, 1892 No. 729 (to March 31, 1893)

- Law March 30, 1893 No. 164 (to June 30, 1893)

- Law June 30, 1893 No. 338 (to August 31, 1893)

${ }^{1}$ Date of publication on the Gazzetta Ufficiale del Regno d'Italia (GU). 


\section{REFERENCES}

Admati, Anat R.; and Hellwig, Martin (2013) The Bankers' New Clothes: What's Wrong with Banking and What to Do About It, Princeton and Oxford, Princeton University Press, pp. xv, 398.

Alessandri, Piergiorgio; and Haldane, Andrew G. (2009) Banking on the State, London, Bank of England, pp. 30.

Alvi, Geminello (2004) "L'abominevole Tanlongo e il crac della Banca Romana," Corriere della Sera, February 8, 2004, p. 29.

Atti Parlamentari (1892) "Tornata del 20 dicembre: Resoconto stenografico," Atti Parlamentari, Camera dei Deputati, XVIII Legislatura, Sessione 1892-93, Discussioni, pp. 684-725.

Atti Parlamentari (1893a) "Tornata di giovedì 26 gennaio 1893: Resoconto stenografico," Atti Parlamentari, Camera dei Deputati, XVIII Legislatura, Sessione 1892-93, Discussioni, pp. 871-902.

Atti Parlamentari (1893b) "Tornata di giovedì 23 novembre 1893: Resoconto stenografico," Atti Parlamentari, Camera dei Deputati, XVIII Legislatura, Sessione 1892-93, Discussioni, pp. 6333-83.

Bertoldi, Silvio (1993) "Tanlongo, il maestro di Calvi e Sindona," Corriere della Sera, April 26, 1993, p. 19.

Biagini, Gustavo (1889) Relazione all'Illustrissimo Sig. Comm. Giuseppe Alvisi, Senatore del Regno, Camera dei Deputati, Archivio Storico, available online at the page http://archivio.camera.it/patrimonio/archivio_della_camera_regia_1848_1943/guida:ITCD_0 $\underline{0100 \quad 00015}$ (accessed on February 22, 2017).

Bonelli, Franco; and Cerrito, Elio (2003), "Mopmenti della formazione di una banca centrale in Italia, 1894-1913" in Cotula et al. (2003), pp. 59-98.

Buch, Claudia M.; and Prieto, Esteban (2014) "Do Better Capitalized Banks Lend Less? Long-Run Panel Evidence from Germany,” International Finance 17(1), pp. 1-23.

Cardarelli, Sergio (2006) "Il tramonto del free banking in Italia: I tentativi di riforma bancaria di Majorana Calatabano (1877-1879)," Banca d'Italia, Quaderni dell'Ufficio Ricerche Storiche 14, pp. 41. 
Civiltà Cattolica (1893) "Lavori della Camera dei Deputati; ispezione sulle banche,” available online at the page

http://www.eleaml.org/ne/camorre/civilta_cattolica_1893 Tanlongo_Cuciniello_banche 201 6.html (accessed on February 22, 2017).

Confalonieri, Antonio (1974) Banca e industria in Italia, 1894-1906, vv. I-II, Milan, Banca Commerciale Italiana, pp. 505, 411.

Conterio, Alberto (2011) "Lo scandalo della Banca Romana - 1893," available online at the page http://archiviostorico.blogspot.com/2011/09/lo-scandalo-della-banca-romana-1893.html (accessed on February 22, 2017).

Cotula, Franco; de Cecco, Marcello; and Toniolo, Gianni (eds.) (2003) La Banca d'Italia: Sintesi della ricerca storica, 1893-1960, Rome and Bari, Laterza, pp. xix, 716.

Croce, Benedetto (1947) Storia d'Italia dal 1871 al 1915, Bari, Laterza, pp. viii, 379.

de Bonis, Riccardo; and Silvestrini, Andrea (2013) “The Italian financial cycle: 1861-2011," Banca d'Italia, Temi di Discussione 936, pp. 39.

de Bonis, Riccardo; Farabullini, Fabio; Rocchelli, Miria; and Salvio, Alessandra (2012) "Nuove serie storiche sull'attività delle banche e altre istituzioni finanziarie dal 1861 al 2011: cosa ci dicono?" Banca d'Italia, Quaderni di Storia Economica 36, pp. 67.

de Cecco, Marcello (1993) "L'Italia e il sistema finanziario internazionale, 1860-1936," in Cotula et al. (2003), pp. 3-58.

della Paolera, Gerardo; and Taylor, Alan M. (2001) "A Monetary and Financial Wreck: The Barings Crisis, 1890-91," in: della Paolera, Gerardo; and Taylor, Alan M. (eds.) (2001) Straining the Anchor: The Argentine Currency Board and the Search for Macroeconomic Stability., 1880- 1935, University of Chicago Press, pp. 67-79.

de Mattia, Renato (ed.) (1967) I bilanci degli istituti di emissione italiani dal 1845 al 1936, altre serie storiche di interesse monetario e fonti, v.I, Rome, Banca d'Italia, part I, pp. cxxvii, 425; part II, pp.

de Mattia, Renato (ed.) (1978) Storia del capitale della Banca d'Italia e dei suoi predecessori (con appendici), Rome, Banca d'Italia, v. III, part II (Appendici), pp. xiii, 5431122.

di Nardi, Giuseppe (1953) Le banche di emission in Italia nel secolo XIX, Turin, UTET, pp. Xii, 436. 
Duggan, Christopher (2002) Francesco Crispi 1818-1901: From Nation to Nationalism, New York, Oxford University Press, pp. xii, 777.

Giani, Leonardo; and Vannini, Riccardo (2010) "Toward an Evolutionary Theory of Banking Regulation: The United States and Italy in Comparison," Review of Banking and Financial Law 29(2), pp. 405-39.

Gigliobianco, Alfredo; and Giordano, Claire (2010) "Economic Theory and Banking Regulation: The Italian Case (1861-1930s)," Banca d'Italia, Quaderni di Storia Economica 5, pp. 71.

Gigliobianco, Alfredo; Giordano, Claire; and Toniolo, Gianni (2009) "Innovation and Regulation in the Wake of Financial Crises in Italy (1880s-1930s), Financial Market Regulation in the Wake of Financial Crises: The Historical Experience Conference, pp, 4573. Available at SSRN at the page: https://ssrn.com/abstract $=2101710$ (accessed on February $22,2017)$.

Goodhart, Charles; and Delargy, P. J. R. (1998) "Financial Crises: Plus ça Change, plus c'est la Même Chose," International Finance 1(2), pp. 261-87.

Grapanzano, Guido; and Giulianini, Ermenegildo (2010) La Cartamoneta Italiana, Corpus Notarum Pecuniariarum Italiae, Volume II, Milan, Moruzzi Numismatica, pp. 798; quoted from the website http://www.moruzzi.it/la banca_romana_durante il_regno_d italia.html (accessed on February 22, 2017).

Haldane, Andrew G. (2012) “The Doom Loop,” London Review of Books 34(4), pp. 21-2.

Hautcoeur, Pierre-Cyrille; Riva, Angelo; and White, Eugene N. (2014) "Floating a "Lifeboat:" The Banque de France and the Crisis of 1889," NBER Working Paper 20083, pp. 44.

ICS (1958) Sommario di statistiche storiche italiane, 1861-1955, Rome, Istituto Centrale di Statistica, pp. 233.

Jordà, Òscar; Richter, Björn; Schularik, Moritz; and Taylor, Alan M. (2017) "Bank Capital Redux: Solvency, Liquidity, and Crisis,” NBER Working Paper 23287, pp. 37, A-16.

Kaminsky, Graciela L.; and Reinhart, Carmen M. (1999) "The Twin Crises: The Causes of Banking and Balance-of-Payments Problems," American Economic Review 89(3), pp. 473500 . 
Kindleberger, Charles Poor (1996) Manias, Panics, and Crashes, New York, Wiley, pp. xvii, 263.

Mack Smith, Denis (2003) Storia d'Italia dal 1861 al 1997, Rome and Bari, Laterza, pp. vii, 703 (English original, 1997: Modern Italy. A Political History, London, Yale University Press, pp. 534).

Macrì, Enzo (1993) I ladri di Roma: 1893 scandalo alla banca Romana: politici, giornalisti, eroi de lRisorgimento all 'assalto del denaro pubblico, Milan, Mondadori, p. 336.

Manacroda, Gastone (1968) Crisi economica e lotta politica in Italia, 1892-1896, Turin, Einaudi, pp. 217.

Mitchener, Kris James; and Weidenmier, Marc D. (2007) "The Baring Crisis and the Great Latin American Meltdown of the 1890s," NBER Working Paper 13403, pp. 53.

Mordini, Antonio; Paternostro, Alessandro; Fani, Cesare; Bovio, Giovanni; Pellegrini, Antonio; Sineo, E.; and Suardi, Gianforte (1893) Relazione della Commissione d'inchiesta parlamentare sulle banche, in: Atti Parlamentari (1893b), pp. 6349-83.

Nascimbeni, Giulio (1974) “Come 1'Italia umbertina superò lo scandalo della Banca Romana," Corriere della Sera March 3, 1974, p. 5

Natoli, Sandra; Piselli, Paolo; Trigluia, Ivan; and Vercelli, Francesco (2016) 'L'Archivio Storico del Credito in Italia,” Banca d'Italia, Quaderni di Storia Economica n. 36, pp. 72.

Negri, Guglielmo (2003) "Giolitti e la nascita della Banca d'Italia nel 1893," in Cotula et al. (2003), pp. 59-98.

Poddi, Stefano (2016) "Lo scandalo della Banca Romana," published on the internet at teh website http://www.cartamonetaitaliana.com/lista-articoli/52-lo-scandalo-della-bancaromana.html\# (accessed on February 22, 2017).

Quilici, Nello (1935) Banca romana, Milan, Mondadori, pp. 731.

Reinhart, Carmen M.; and Reinhart, Vincent R. (2008) "Capital Flow Bonanza: An Encompassing View of the Past and Present,” NBER Working Paper 14321, pp. 68.

Saladino, Salvatore (1974) "Parliamentary Politics in the Liberal Era: 1861-1914," in: Tannenbaum and Noether (1974), pp. 27-51.

Spinelli, Franco; and Fratianni, Michele (1991) Storia monetaria d'Italia: l'evoluzione del sistema monetario e bancario, Milan, Arnoldo Mondadori, pp. 734. 
SVIMEZ (1954) Statistiche sul Mezzogiorno d'Italia, 1861-1953, Rome, Associazione per lo Sviluppo dell'Industria nel Mezzogiorno, pp. xii, 1096.

Talamona, Mario (1993) “Tangenti romane, anno 1893," Corriere della Sera July 3, 1993, p. 24.

Tannenbaum, Edward R.; and Noether, Emiliana O. (1974) Modern Italy. A Topical History since 1861, New York, New York University Press, pp. xxix, 395. 